

\section{Editorial Director}

Jan Smets, Member of the Board of Directors of the National Bank of Belgium

\section{Statement of purpose:}

The purpose of these working papers is to promote the circulation of research results (Research Series) and analytical studies (Documents Series) made within the National Bank of Belgium or presented by external economists in seminars, conferences and conventions organised by the Bank. The aim is therefore to provide a platform for discussion. The opinions expressed are strictly those of the authors and do not necessarily reflect the views of the National Bank of Belgium.

\section{Orders}

For orders and information on subscriptions and reductions: National Bank of Belgium,

Documentation - Publications service, boulevard de Berlaimont 14, 1000 Brussels

Tel +32 $22212033-$ Fax +32 2213042

The Working Papers are available on the website of the Bank: http://www.nbb.be

\section{(c) National Bank of Belgium, Brussels}

All rights reserved.

Reproduction for educational and non-commercial purposes is permitted provided that the source is acknowledged.

ISSN: $1375-680 \mathrm{X}$ (print)

ISSN: $1784-2476$ (online) 


\begin{abstract}
This paper determines the relative importance of technical efficiency and reallocation for aggregate productivity growth in a small open European economy. To this end we use a dataset containing all Belgian firms active in the private sector, both services and manufacturing. We observe at the firm level a number of factors that have been shown to be drivers of productivity differences across firms. More precisely, we have information on human capital such as the level of education and the amount of on-the-job training received by the employees. Moreover we observe the international activities of the firms such as imports and exports. This allows us to make a careful analysis of the micro foundations of aggregate productivity growth by applying the decomposition introduced by Petrin and Levinsohn (2012). The outcome of this exercise will not only provide us with a better understanding of the slowdown of productivity growth in Europe over the past decades, but also give an indication on the role of different productivity drivers in this process.
\end{abstract}

JEL classification: D24, O47, C23.

Keywords: Productivity, Productivity Decomposition.

\title{
Authors:
}

Ilke Van Beveren, Lessius Department of Business Studies, KU Leuven, e-mail: ilke.vanbeveren@kuleuven.be.

Stijn Vanormelingen, HU Brussels, KU Leuven.

The views expressed in this paper are those of the author and do not necessarily reflect the views of the National Bank of Belgium or any other institutions to which the author is affiliated. 


\section{TABLE OF CONTENTS}

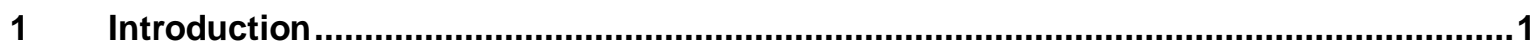

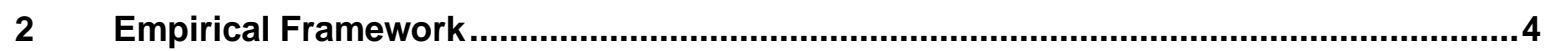

2.1 Petrin and Levinsohn (2012) Decomposition................................................................. 4

2.2 Griliches and Regev (1995) Decomposition ..............................................................

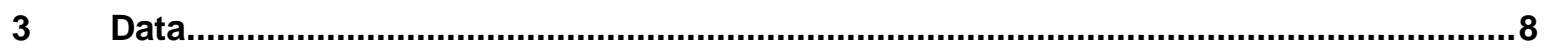

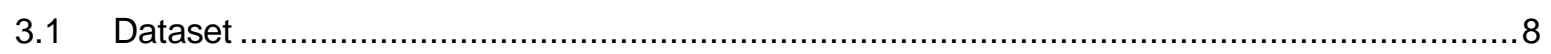

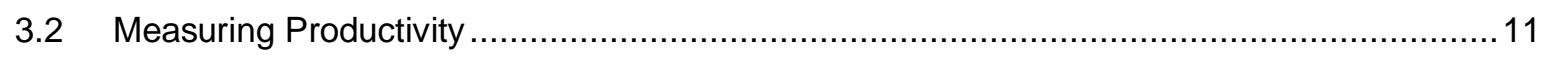

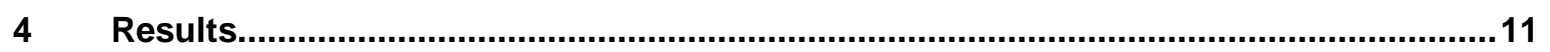

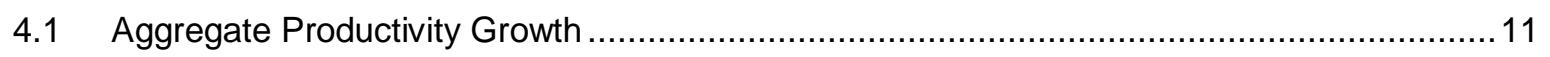

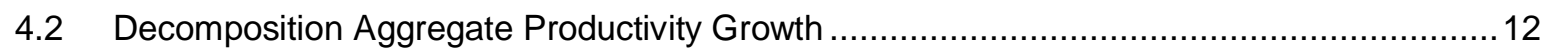

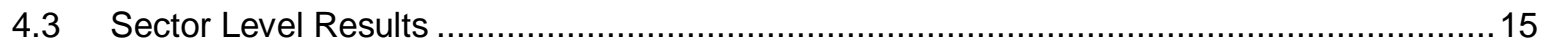

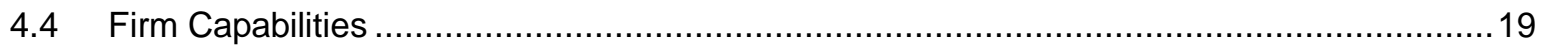

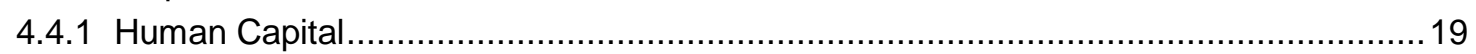

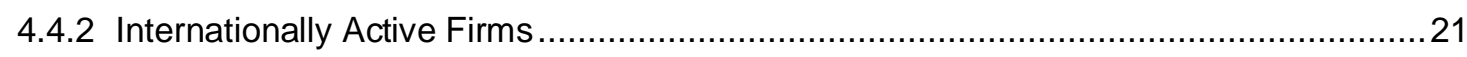

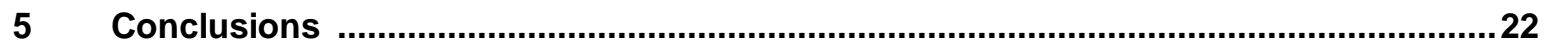

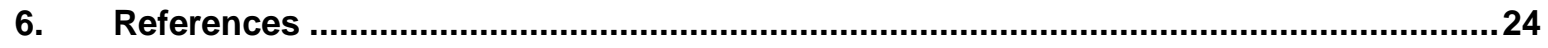

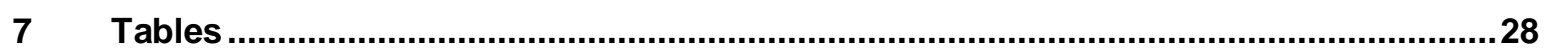

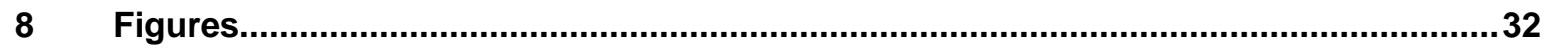

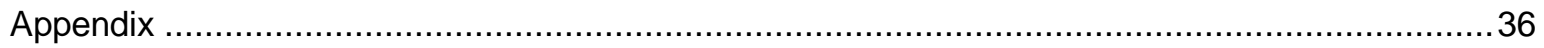

National Bank of Belgium - Working papers series ............................................................. 43 


\section{Introduction}

Economists and policy makers have always had a keen interest in understanding how firms turn inputs into outputs. Productivity, which measures the efficiency with which this conversion occurs, has received special attention as it directly affects the performance of countries and regions. At the aggregate level for example Jones and Romer (2010) document that over $50 \%$ of GDP per capita differences across countries are accounted for by productivity differences. In Europe, a substantial deceleration in both labor and total factor productivity growth has been recorded since the 1990s, relative to the United States putting downward pressure on GDP per capita growth (van Ark et al., 2008).

At the firm or plant level, researchers have found substantial heterogeneity in productivity across firms. Moreover these differences are proven to be persistent over time. An increasing number of papers has started to analyze the determinants of firm level productivity in recent years (cf. Syverson, 2011 for an overview). These studies can be related to the recent work of Sutton (2012) analyzing firm capabilities. Sutton considers the 'revealed' capability of a firm as its 'underlying capability', which consists of the set of elements of 'know-how' or 'working practices' held collectively by the group of individuals comprising the firm. Firms can acquire the necessary capabilities by investing in human capital (hiring skilled workers or investing in firm-specific human capital through training, cf. Konings and Vanormelingen, 2011) or, more indirectly, through spillovers resulting from its relationships with and interaction with foreign and domestic suppliers and competitors. Corry et al.(2011) show for the UK that that most of the productivity improvements were generated through the increased importance of skills and new technologies.

Not only firm level productivity growth matters for aggregate productivity growth, but also the reallocation of resources across different firms. The international trade literature has studied the relationship between firm level productivity and internationalization intensively since the 1990s, both theoretically and empirically (see Bernard et al, 2012; Mayer and Ottavianio, 2008). These studies demonstrate that the most productive firms select themselves 
into international markets and that trade liberalization will induce a process of creative destruction. Hence, from a policy point of view promoting intra-industry competition is important, leading the most productive firms to replace the least productive ones.

The importance of firm level productivity growth relative to the reallocation of resources between firms with different productivity levels in aggregate productivity growth is likely to differ across sectors. For example Baldwin and $\mathrm{Gu}$ (2011) find that the manufacuring industries best fit in the active learning model (Ericson and Pakes, 1995) where firms can improve their productivity after entry by making investments with an uncertain return. Firms realizing productivity improvements expand over time while firms witnessing productivity decreases contract and ultimately exit. The retail sector on the other side would be best described by a passive learning model where a firm enters with a given time-invariant productivity level. Over time, the firm updates its believes about its underlying productivity level based on the realized profits and either exits or stays in the market. These results are consistent with the findings of Foster et al. (2006) who show how productivity growth in the retail sector is almost entirely due to the entry of more productive establishments and exit of less productive establishments. However, most of the studies up to date are limited to the manufacturing sectors, mainly due to data limitations.

To determine the importance of firm level productivity growth versus the reallocation of resources, most papers have computed sector or country level aggregate productivity growth by using the input-or output-share weighted averages of productivity growth at the firm level. Subsequently, aggregate growth is decomposed to determine to which extent growth is due to increases in technical efficiency or reallocation of resources (e.g. Baily et al. (1992), Olley and Pakes (1996), Griliches and Regev (1995) and Foster et al. (2001)). However, in a recent paper Petrin and Levinsohn (2012) show that these definitions of aggregate productivity growth are not necessarily linked to the classic definition of aggregate productivity growth, namely aggregate value added growth that cannot be accounted for by input changes. They show how to construct from firm level data a measure for aggregate productivity growth in line with the classic definition, which can then be decomposed to measure the importance 
of technical efficiency versus reallocation effects.

We follow Petrin and Levinsohn (2012) and determine the relative importance of technical efficiency and reallocation for aggregate productivity growth in a small open European economy. To this end we use a dataset containing all Belgian firms active in the private sector, both services and manufacturing. We observe at the firm level the necessary variables to estimate productivity as well as a number of factors that have been shown to be drivers of productivity differences across firms. More precisely, we have information on human capital such as the level of education and the amount of on-the-job training received by the employees. Moreover we observe the international activities of the firms such as imports and exports. This allows us to make a careful analysis of the micro foundations of aggregate productivity growth. The outcome of this exercise will not only provide us with a better understanding of the slowdown of productivity growth in Europe, but also give an indication of the importance of the different productivity drivers to both aggregate and firm level productivity growth.

By doing so we contribute to the literature along several dimensions. First, we are the first to apply the Petrin and Levinsohn (2012) approach in a European context. Second, we include the services sector in our analysis. We do not only decompose aggregate productivity in the services sector, but include as well international trade in services as a productivity driver. Third, while most studies consider a single determinant of productivity at a time, our rich dataset allows us toanalyze the role of each of these factors in explaining productivity growth at the firm level as well as at the aggregate level.

Our findings suggest that reallocation is the largest and most stable component of aggregate productivity growth, whereas within-firm productivity improvements account for a smaller but also much more volatile component of productivity growth. Hence, changes in aggregate productivity growth are driven mainly by fluctuations in within-firm productivity improvements. At the sector level, within-firm productivity improvements are realized mainly by firms active in the manufacturing and telecommunication sectors. In general, firms and sectors that invest in human capital (by providing training opportunities and/or 
by hiring relatively skilled people) and/or participate actively on the international market, outperform their counterparts. Finally, the relatively poor performance of the wholesale and retail sector in Belgium can be related to the strict regulations that apply to the sector in most of continental Europe (Baldwin and $\mathrm{Gu}$, 2011, Conway and Nicoletti, 2006), hence suggesting that liberalization may yield additional productivity improvements in the future. Overall, while the services sector continues to grow in terms of value added and employment, its contribution to overall productivity growth remains rather limited.

The remainder of the text is structured as follows. The second section shows the empirical framework used to compute aggregate productivity while discussing its micro-foundations. The third section describes the dataset(s) used while the fourth section presents and discusses the results Finally the last section concludes.

\section{Empirical Framework}

This section presents the decompositions of aggregate productivity growth used in the analysis. We will mainly focus on the novel Petrin and Levinsohn (2012) decomposition, but will present as well the more standard Griliches and Regev (1995) decomposition, which will be executed as a point of comparison.

\subsection{Petrin and Levinsohn (2012) Decomposition}

This section briefly describes the method proposed by Petrin and Levinsohn (2012) to measure aggregate productivity growth and decompose it into its micro-level foundations. The setting is the following. There are $N$ firms in the industry and to produce $Q_{i t}$ units of output in period $t$, firm $i$ combines $K$ primary inputs, for example different kinds of capital and labor, $X_{i t}=\left(X_{i 1}, X_{i 2}, \ldots, X_{i K}\right)$ with intermediate inputs $M_{i t}=\left(M_{i t 1}, M_{i 2 t}, \ldots, M_{i J t}\right)$ according to the production function $Q^{i}$,

$$
Q_{i t}=Q^{i}\left(X_{i t}, M_{i t}, \omega_{i t}\right)-F_{i t}
$$


where $\omega_{i t}$ represents firm level total factor productivity and $F_{i t}$ are all fixed and sunk costs incurred by firm $i$, normalized to the equivalent of foregone output. The total amount of output that goes to final demand $Y_{i t}$ is then

$$
Y_{i t}=Q_{i t}-\sum_{j} M_{j i t}
$$

with $\sum_{j} M_{j i}$ the part of firm $i$ 's production that is used as an intermediate in other firms or in firm $i$. Petrin and Levinsohn (2012) then define aggregate productivity growth as the difference between the change in aggregate final demand and the change in total expenditures on primary inputs:

$$
A P G_{t} \equiv \sum_{i} P_{i t} d Y_{i t}-\sum_{i} \sum_{k} W_{i k t} d X_{i k t}
$$

with $W_{i k t}$ the cost of primary input $k$. In growth rates, Equation 2 can be written as:

$$
A P G_{G, t}=\sum_{t} D_{i t} d \ln Y_{i t}^{*}-\sum_{i} \sum_{k} c_{i k t} d \ln X_{i k t}
$$

where $D_{i t}=\frac{P_{i t} Q_{i t}}{\sum_{i} P_{i t} Y_{i t}}$ is the Domar (1961) weight, $d \ln Y_{i t}^{*}=d Y_{i t} / Q_{i t}$ and $c_{i k t}=\frac{W_{i k t} X_{i k t}}{\sum_{i} P_{i t} Y_{i t}}$, the share of cost of input $k$ in aggregate demand. Although we do not observe the amount of a plant's output that goes to final demand, the National Accounting Identity shows that aggregate final demand is equal to aggregate value added and moreover that $\sum_{t} D_{i t} d \ln Y_{i t}^{*}=$ $\sum_{t} D_{i t}^{v} d \ln V A_{i t}$ where $D_{i t}^{v}=\frac{V A_{i t}}{\sum_{i} V A_{i t}}$, the share of value added of firm $i$ in total value added.

Petrin and Levinsohn (2012) show how aggregate productivity growth can be decomposed into a technical efficiency term (TE) a reallocation term (RE) and a fixed costs term (F). More precisely $A P G_{t}=T E+R E+F$ with

$$
\begin{aligned}
T E & \equiv \sum_{i} P_{i t} d \omega_{i t} \\
R E & =\sum_{i} \sum_{k}\left(P_{i t} \frac{\partial Q_{i t}}{\partial X_{k}}-W_{i t k}\right) d X_{i t k}+\sum_{i} \sum_{j}\left(P_{i t} \frac{\partial Q_{i t}}{\partial M_{j}}-P_{j t}\right) d M_{i j t} \\
F & =-\sum_{i} P_{i t} F_{i t}
\end{aligned}
$$

Aggregate productivity growth can first of all increase if the average firm level productivity increase. Moreover, aggregate productivity growth can occur through reallocation of 
resources from low marginal value activities to high marginal value activities (relative to marginal costs). If for example marginal costs are constant across firms, the reallocation of one unit of input from firm $i$ to firm $s$, would increase the value of output by $P_{s t} \frac{\partial Q_{s t}}{\partial X_{k}}-P_{i t} \frac{\partial Q_{i t}}{\partial X_{k}}$ while aggregate input use remains constant, leading thus to an increase in aggregate productivity. In a neoclassical setting without frictions, the value of the marginal product is equal to the marginal cost, leaving no room for improvements in aggregate productivity through reallocation of resources. In reality, markups, taxes and adjustment costs all create gaps between the value of the marginal product and marginal costs and for example the reallocation of resources to firms with higher markups increases aggregate productivity growth.

In growth rates, the decomposition of aggregate productivity growth can be written as:

$$
A P G_{G, t}=\sum_{i} D_{i t} d \ln \omega_{i t}+\sum_{i} D_{i t} \sum_{k}\left(\varepsilon_{i k}-s_{i k t}\right) d \ln X_{i k t}+\sum_{i} D_{i t} \sum_{j}\left(\varepsilon_{i j}-s_{i j t}\right) d \ln M_{i j t}-\sum_{i} D_{i t} d \ln F_{i t}
$$

where $\varepsilon_{i k}$ and $\varepsilon_{i j}$ are the output elasticities of primary and intermediate inputs and $s_{i k t}=$ $\frac{W_{i k t} X_{i k t}}{P_{i t} Q_{i t}}$ are the revenue shares of each input. If intermediate inputs are separable in the output production function, Petrin and Levinsohn (2012) show the growth rate formulation in terms of the value added production function to be:

$$
A P G_{G, t}=\sum_{i} D_{i t}^{v} d \ln \omega_{i t}^{v}+\sum_{i} D_{i t}^{v} \sum_{k}\left(\varepsilon_{i k}^{v}-s_{i k t}^{v}\right) \Delta \ln X_{i k t}+\sum_{i} D_{i t}^{v} \sum_{j}\left(\varepsilon_{i j}^{v}-s_{i j t}^{v}\right) \Delta \ln M_{i j t}-\sum_{i} D_{i t}^{v} \Delta \ln F_{i t}
$$

where again, $D_{i t}^{v}$ is equal to the firm's share in total value added, $s_{i k t}^{v}=\frac{W_{i k t} X_{i k t}}{V A_{i t}}$ is now the value added share of each input and the output elasticities, $\varepsilon_{i j}^{v}$, are now those for the value added production function. They can be shown to be equal to the elasiticites from the output production function divided by 1 minus the share of intermediates in total revenue, i.e. $\varepsilon_{i j}^{v}=\frac{\varepsilon_{i j}}{1-\sum_{j} s_{i j}}$. Likewise, $\omega_{i t}^{v}$ is the residual of the value added production function. Given that the small firms do not report sales, we will focus on the value added specification for the remainder of the analysis.

To write equations 3 and 5 in discrete time, we use Tornquist-Divisia approximations. 
The growth rate of aggregate productivity can be written as:

$$
A P G_{t}^{P L}=\sum_{i} \bar{D}_{i t}^{v} \Delta \ln V A_{i}-\sum_{i} \sum_{k} \bar{c}_{i k t} \Delta \ln X_{i k t}
$$

where $\bar{D}_{i t}^{v}$ is the average of firm $i$ 's value added share from year $t-1$ to year $t$ and $\bar{c}_{i k t}$ the average across two periods of firm $i$ 's expenditure share of input $k$ in total value added. The decomposition of aggregate productivity growth can be written as:

$$
\begin{aligned}
A P G_{G}^{P L}= & \sum_{i} \bar{D}_{i t}^{v} \Delta \ln \omega_{i t}^{v} \quad T E \\
& +\sum_{i} \bar{D}_{i t}^{v} \sum_{k}\left(\varepsilon_{i k}^{v}-\bar{s}_{i k t}^{v}\right) \Delta \ln X_{i k t}+\sum_{i} \bar{D}_{i t}^{v} \sum_{j}\left(\varepsilon_{i j}^{v}-\bar{s}_{i j t}^{v}\right) \Delta \ln M_{i j t} \quad R E \\
& -\sum_{i} \bar{D}_{i t}^{v} \Delta \ln F_{i t} \quad F
\end{aligned}
$$

where again a bar denotes the average of the variable across two time periods. Note that when estimating a value added production function, the computed value added residual is

in fact $\ln \omega_{i t}^{v}=\ln V A_{i t}-\left(\sum_{k} \varepsilon_{i k} \ln X_{i k}\right)-\sum_{j}\left(\varepsilon_{i j}^{v}-\bar{s}_{i j t}^{v}\right) \Delta \ln M_{i j t}$, the estimated residual will contain the reallocation terms associated with intermediate inputs. These terms are only equal to zero of if the elasticity of output with respect to an intermediate is equal to the share of expenditures for that intermediate in total revenue. Since we only observe total revenue for a subsample of firms, we focus on value added results despite this shortcoming, but we will perform a robustness check on the subsample of firms reporting revenue.

\subsection{Griliches and Regev (1995) Decomposition}

Several other approaches for aggregating and decomposing productivity growth have been applied in the literature. Most of these decompositions use the share weighted sum of firm level productivity as a measure of aggregate productivity growth To compute the weighted average, either input or output weights can be used., namely $A P G_{t}^{G R}=\sum_{i} s_{i t} \Delta \omega_{i t}$. Griliches 
and Regev (1995) show how aggregate productivity growth can be decomposed as:

$$
\begin{aligned}
& A P G_{t}^{B H C}= \sum_{i \in S} \bar{s}_{i t} \Delta \omega_{i t}+\sum_{i \in S} \Delta s_{i t}\left(\bar{\omega}_{i t}-\bar{P}_{t}\right) \\
& T E+R E \\
&+\sum_{i \in N} s_{i t}\left(\omega_{i t}-\bar{P}_{t}\right)-\sum_{i \in X} s_{i t-1}\left(\omega_{i t-1}-\bar{P}_{t}\right) \\
&+\quad E E+X E
\end{aligned}
$$

where a bar over the variable denotes the average over two time periods and $P$ denotes the aggregate productivity level in the sector/economy. Aggregate productivity growth can occur through firms becoming more efficient (the technical efficiency term, also called within firm component) as well as by reallocation of resources to firms being more productive than the average (the reallocation term, also called between firm component). Moreover when entrants are more productive than the average, aggregate productivity increases and likewise if exiters are less productive than the average (the entry and exit terms). As Petrin and Levinsohn (2012) note, the reallocation terms (including the entry and exit terms) are problematic as they could be negatively related to final demand and productivity growth defined at the aggregate level. For the sake of comparison we will also perform a decomposition of aggregate productivity growth following Griliches and Regev. (1995). ${ }^{1}$

\section{Data}

\subsection{Dataset}

We make use of several databases to compute productivity growth and infer the contributions of different firm types. First, we use data from the annual accounts of Belgian firms for the period 1997-2009. In principle, all limited-liability firms in Belgium are required to file their annual accounts to the National Bank of Belgium (NBB) and we select all firms active in the private sector (NACE Rev 1.1 codes 1-74). The required variables for estimating productivity using value added production functions are reported. To compute real value

\footnotetext{
${ }^{1}$ In practice we follow the standard in the literature and perform the decomposition in equation (9) for each sector and subsequently take a weighted average of these sector level growth rates to compute economy-wide aggregate productivity growth.
} 
added, we deflate nominal value added by an industry value added price index obtained from EU Klems. ${ }^{2}$ As a measure for labor input, we observe the number of employees at a firm (full-time equivalent) as well as the number of hours worked. We have information on the different types of tangible fixed assets (buildings, machinery and equipment, transport equipment). We construct a measure for the real capital stock using the book value of the firm's assets and the reported depreciation. For details on the construction of the real capital stock, we refer to the Appendix. The user cost of capital is defined as $r_{i t} \equiv\left(\delta_{i t}+r_{t}\right) P_{t}$ with $\delta_{i t}$ the reported depreciation rate of firm $i$ in period $t$ and $r_{t}$ the long-term interest rate in period $t$. Finally, $P_{t}$ represents the price index of gross fixed capital formation.

A subsample of large firms has to file complete annual accounts ${ }^{3}$ which additionally provide information on turnover and material costs, allowing us to estimate revenue production functions. We will focus however mainly on the full sample of firms, but provide a robustness check focusing on the larger firms in order to keep the sample as representative as possible for the whole Belgian private sector. Moreover, reallocation of resources is likely to be more important for small firms compared to large firms. For example Foster et al. (2002) find the pace of job reallocation as well as entry and exit rates to be a sharply decreasing function of firm size in the US retail sector. Excluding the small firms would likely lead us to underestimate the importance of reallocation in productivity growth. Next to the standard variables, the annual report includes the "social balance sheet" which contains rich information on the workforce including their education level, investments in on-the-job training, both formal as well as informal and the number of managers, blue-collar workers and white collar workers. ${ }^{4,5}$

\footnotetext{
${ }^{2}$ The price indices are available for the period 1996-2007 at the NACE 2 or NACE 3 digit level. From 2007 to 2009 these are only available at the (sub)section level.

${ }^{3}$ Firms that are affiliated to other firms, publicly listed firms and firms that exceed at least two of the three cutoff criteria in terms of employment (50 employees), balance sheet total (€3.65mio) and turnover (€euro7.3mio) need to file complete accounts.

${ }^{4}$ The data on the education level is only available for large firms.

${ }^{5}$ There have been substantial changes in the social balance sheet starting in 2008. Most importantly, employment by skill had to be reported only in flows - i.e. the educational level of the workers entering and leaving the firm - prior to 2008, while it has to be reported in stocks starting in 2008. The changes in the social balance sheet variables imply that the data before and after the change are difficult to compare. We will therefore not include 2008 and 2009 in the analysis when we investigate how different human capital profiles of firms relate to their productivity growth patterns.
} 
The second database contains imports and exports of goods and covers the full population of firms that report trading activities in Belgium. The data include both intra-EU and extraEU imports and export flows. For intra-EU trade flows, firms are only required to report their trade if its value exceeds a particular cutoff. The data are recorded at the firm-productcountry-year level, separately for each flow. We aggregrate the trade flows to the firm-year level to define firm-specific indicators of firms' trading status.

The third database contains imports and exports of services and covers the full population. These data are limited to the period 1995-2005. Starting 2006, the data collection procedure has changed, resulting in a different (smaller) population. The data are recorded at the firm-service-country-year level. We aggregate these data to the firm-year level to obtain firm-specific indicators of firms' trading status. Due to these data limitations, we need to limit the sample to the period 1997-2005 when we analyze the relationship between the trading status of firms in services and aggregate productivity growth.

The databases are merged together using the unique firm level VAT number, resulting in an unbalanced panel data set of 216,805 firms active in the Belgian private sector. The dataset covers around $75 \%$ of total private sector employment. The restricted dataset of large firms reporting the educational level of the employees and total sales consists of 21,751 firms but still covers around $55 \%$ of total employment. Table 1 displays some summary statistics of both the full sample and the restricted sample of large firms. The average firm employs almost 15 employees and generates a yearly value added of around 1 million euros. The average share of labor costs and capital costs in value added $\left(\alpha_{l}\right.$ and $\left.\alpha_{k}\right)$ are respectively equal to .62 and .20. The average size of large firms is equal to 102 employees and the cost shares of the different inputs in total revenue ( $\beta_{X}$ 's) are equal to .22 for labor, .56 for materials and .05 for capital. 


\subsection{Measuring Productivity}

To infer total factor productivity, we estimate value added production functions following Wooldridge (2009). We use investment as a proxy to invert out productivity (Olley and Pakes, 1996) and estimate different production function parameters for each two digit NACE

Rev1.1 sector. ${ }^{6}$ For our main results we rely on the more flexible translog production function instead of the standard Cobb-Douglas. The main advantage is that the output elasticities are allowed to vary across firms within a sector, which could be important as these elasticities are part of the reallocation terms. The estimated production function coefficients can be used to compute total factor productivity:

$$
\ln \omega_{i t}=a v_{i t}-\widehat{\beta}_{l} l_{i t}-\widehat{\beta}_{k} k_{i t}-\widehat{\beta}_{l l}\left(l_{i t}\right)^{2}-\widehat{\beta}_{k k}\left(k_{i t}\right)^{2}-\widehat{\beta}_{l k} l_{i t} k_{i t}
$$

with $a v_{i t}$ the natural logarithm of deflated value added, $l_{i t}$ the natural loggarithm of labor input (either number of hours or number of employees) and $k_{i t}$ the natural logarithm of the real capital stock.

\section{Results}

\subsection{Aggregate Productivity Growth}

As a starting point we focus on value added and productivity growth for the entire private sector. Figure 1 displays the growth rate of GDP reported by the National Bank of Belgium and the growth rate of total value added in our sample. In general, the value added growth follows closely GDP growth as it should (although we exclude the public sectors in our data set). When turning to the different contributions of inputs and productivity - following Petrin and Levinsohn (2012) - to the growth in value added in Table 2, one can see that on average total factor productivity contributed positively to economic growth over the sample period. Growth in labor and capital inputs was limited over the 12 year sample period, in

\footnotetext{
${ }^{6}$ Due to the low number of observations, sector 16 - Manufacture of Tobacco Products is combined with sector 15 - Manufacture of Food Products. Sector 23 - Manufacture of Energy Products is combined with sector 24 - Manufacture of Chemical Products. Finally, sectors 30 - Manufacture of Electrical Equipment and 32 - Manufacture of Radio and Telecom. Equipment are merged together.
} 
line with expectations for a developed economy like Belgium. Comparing the growth rates of total factor productivity in Figure 2 and Table 2, one can see that the evolution of aggregate productivity growth according to Petrin and Levinsohn (2012) $\left(A P G_{G}^{P L}\right)$ is similar to the evolution in productivity growth reported in the macro database EU Klems, but the level of $A P G_{G}^{P L}$ appears to be higher, namely $1.46 \%$ as opposed to $-0.47 \%$. This can be partly due to the changing skill composition of the labor force. While productivity growth reported in the EU Klems database takes into account the skill structure of the labor force, we have treated the labor stock to be homogeneous. ${ }^{7}$ Aggregate productivity growth computed as the share weighted sum of firm level productivity $\left(A P G_{G}^{G R}\right)$ appears to be more volatile and less related to productivity growth computed using macro data. The correlation between EU Klems productivity growth and $A P G_{G}^{P L}$ and $A P G_{G}^{G R}$ are respectively 0.64 and 0.24 .

\subsection{Decomposition Aggregate Productivity Growth}

Table 3 reports the Petrin and Levinsohn (2012) decomposition of aggregate productivity growth. The reallocation of resources to higher marginal product activities provides a positive and stable contribution to aggregate productivity growth and is on average equal to $1.25 \%$. Average within-firm productivity growth is lower and equal to $0.21 \%$, but its volatility is much higher. The standard deviation of the within term is equal to $1.16 \%$ while its value for the reallocation term is only $0.56 \%$. By consequence fluctuations in aggregate productivity are mainly driven by technical efficiency growth. These results are in line with Petrin et al. (2011) who found similar results for US manufacturing industries. Firm level technical efficiency growth appears to be strongly procyclical as the correlation between value added growth and within firm productivity growth is higher than 0.70 . A possible explanation could be labor hoarding by firms during recessions and the adjustment of labor to negative shocks is happening more through reducing the number of hours worked by an employee instead of through the number of employees employed. As a robustness check, we

\footnotetext{
${ }^{7}$ Note that this can only partly explain the difference in productivity growth as according to the EU Klems database the average yearly contribution of the labor composition to value added is $0.23 \%$ points.
} 
used the number of hours as our measure for labor input. Results are reported in Table C.1. Again, fluctuations in aggregate productivity growth are driven by the technical efficiency term, although technical efficiency is now less procyclical, as expected. ${ }^{8}$

Turning to the reallocation "gap" terms, one can see that labor gets reallocated from low-value activities to higher-value activities. The capital reallocation term is somewhat more volatile, but positive on average. On average the fixed costs term is positive hinting to decreasing fixed costs over time. All in all the residual fixed cost term is relatively small in comparison to total reallocation, indicating that the reallocation of resources from low-value activities to high-value activities do a good job in explaining total reallocation.

The results for the Griliches and Regev (1995) decomposition are reported in Table 4. Again, within-firm productivity growth accounts for only one quarter of aggregate productivity growth. Productivity growth appears to be mainly driven by the entry of firms being more productive than the industry average and the exit of less productive firms. Together they account for around $2 / 3$ of aggregate productivity growth. ${ }^{9}$ The between term - measuring to what extent output gets reallocated to more productive firms - is highly volatile and close to zero on average. The entry term is positive in most years indicating that on average entrants are more productive compared to incumbents. The contribution of entry in 2009 is relatively high. Although the entry rate is low in this crisis year, the entrants are substantially more productive. Similarly, the contribution of exits to aggregate productivity growth is relatively low in spite of a higher exit rate because the productivity difference between exiters and incumbents is smaller compared to other years. These results are in line with results obtained by Hallward-Driemeier and Rijker (2013) for Indonesia in response to the economic crisis in Asia during the1990s. Potential reasons why the crisis would have

\footnotetext{
${ }^{8}$ When using the number of full time equivalents employees as the measure for labor input, the correlation between value added growth and within firm productivity growth is equal to 0.74 . Using the number of hours as labor input this correlation drops to 0.30 .

${ }^{9}$ In principle, the within firm productivity growth in the Griliches-Regev decomposition should be exactly the same as in the Petrin-Levinsohn decomposition. However, recall that we perform the Griliches-Regev decomposition at the sector level - the same level at which the estimation was executed - and subsequently aggregate these sector level results up using value added shares.
} 
such adverse effects are financial constraints faced by firms, as well as temporary restrictions on products or markets imposed by governments when the crisis hits.

Before turning to the sector-level analysis of aggregate productivity growth, we perform a number of robustness checks on the full sample. Results of these alternative decompositions can be found in Appendix C. Table C.1 shows the results of the Petrin and Levinsohn decomposition when we replace the number of employees by the number of hours worked. Firms can adjust the number of hours more easily in response to a positive or negative shock, at least to the extent that they can be adjusted without hiring or firing anyone. This higher flexibility is confirmed by the much higher variation in labour input growth in Table C.1 compared to Table 4. Aggregate productivity growth is on average somewhat higher and more volatile if we rely on the number of hours. While within-firm productivity growth accounts (on average) for less than 15 percent of aggregate productivity growth when we use the number of full-time employees, this value goes up to almost 43 percent when the number of hours is used instead. To avoid measurement error and improve comparability with related literature, we focus on the number of employees as our preferred measure for the production function in what follows.

In Table C.2 we use the deflated book value of tangible fixed assets as a measure for the capital stock. The construction of the real capital stock in the main results could be more sensitive to measurement error in the capital stock as the year-to-year difference controlled for depreciation is taken as total investment, which is subsequently deflated and added to the capital stock. However from C.2,it is clear that the choice for a different way to construct the capital stock hardly affects our results, Table C.2 summarizes the results.

In Table C.3, we perform a similar decomposition, now using a revenue production function, following Equation 4. Again, productivity growth is mainly realized through the reallocation of resources to firms with larger gaps. Within firm (technical efficiency) growth is on average even negative and highly volatile. The material reallocation term is positive in 
most periods, indicating that within firm productivity growth using the value added specification will be upward biased. Average within firm productivity growth computed using the value added production is equal to $0.28 \%$, which should be compared to the average within firm productivity growth using the output production function, i.e. -0.89\%. Although the level of value added within firm productivity growth is higher, both measures are positively correlated with each other.

Finally, Table C.4 shows the result of the decomposition if we rely on a Cobb-Douglas specification for the production function rather than the more flexible translog specification. The choice of estimator only affects the within and reallocation components in the decomposition, aggregate productivity growth is identical in Table C.4 and in Table 3. Results suggest a bigger role for within-firm productivity growth when we rely on the Cobb-Douglas specification and corresponding lower importance of reallocation. The within components are positively correlated across specfications however.

\subsection{Sector Level Results}

Table 5 displays aggregate productivity growth per sector. In line with expectations, largest productivity growth can be found in the Agricultural and Manufacturing sectors. ${ }^{10}$ with respectively an average growth rate of $5.33 \%$ and $1.69 \%$. For these sectors within firm productivity growth - i.e. individual firms improving their productivity level - is the most important contributor while the reallocation of resources across firms accounts for only a minor part of aggregate productivity growth. Productivity growth in the Transport and Communication Sector is high as well, but this is mainly due to the Communications sector. ${ }^{11}$ Productivity growth in the services sectors is in general lower compared to the industrial sectors. Moreover, the reallocation term is more important for the services sectors (again

\footnotetext{
${ }^{10}$ Banks are not included in the Financial sector as they do not file standard annual reports and we choose not to report the results for this sector separately.

${ }^{11}$ Average aggregate productivity growth in the Communications sector (NACE rev 1.1 code 64 ) is equal to $3.97 \%$, of which $2.57 \%$ points is due to within firm productivity growth and $1.40 \%$ is due to reallocation. Average aggregate productivity growth in the Transport and Storage sectors was equal to $1.87 \%$ of which $0.21 \%$ due to within growth and $1.66 \%$ to reallocation.
} 
with the exception of the Communications sectors). Technical efficiency growth is virtually non-existent and even negative for the services sectors (on average across all years of the sample).

In Figure D.1 in the Appendix, we show aggregate productivity growth for a more detailed classification of the sectors. The top sectors in terms of productivity growth are all agricultural or manufacturing sectors. The only services sectors with high productivity growth are the Communication and Computer Services sectors.

One of the advantages of the decomposition proposed by Petrin and Levinsohn (2012) is that it allows to measure the contribution of different types of firms or different sectors to both aggregate factor productivity growth as well as the technical efficiency and reallocation terms decomposition. The result of such an exercise is reported in Figure 3. Clearly, the most important sector for economic growth between 1997 and 2009 was the Business Services sector accounting for over one third of growth in value added. However, growth in this sector mainly occured through the accumulation of labor and capital and the main contributors to productivity growth are the Manufacturing sector and - to a lesser extent - the Post and Telecommunications sector. The picture for the within firm productivity growth is even more striking as the only contributors to growth are the Manufacturing sector and the Post and Telecommunications sector.

Table 6 displays results for the Griliches-Regev decomposition. Results are comparable in that highest productivity growth can be found in the Agricultural, Manufacturing and Telecommunications sectors. While the Wholesale and Retail sector has been identified as one of the main contributors to aggregate productivity growth in the US, productivity growth in Belgium appears to be non-existent. Within-firm productivity growth is strongly negative, compensated by more productive firms becoming larger and the less-productive firms being driven out of the market. For the other non-manufacturing sectors, there is some positve productivity growth for Business Services and Construction, but this growth has been driven by the entry of more efficient firms. The within firm productivity growth is negative. 
The results can be framed in the different models on industry and productivity dynamics (Baldwin and $\mathrm{Gu}, 2011$ ). The services industry appears to be in line with the passive learning model of Jovanovic (1982) where firms are endowed at birth with an unknown productivity level. After entry, firms update their beliefs on this time-invariant productivity level by looking at their realized profitability levels. The less productive firms exit the market while the more productive firms survive. Aggregate productivity growth is thus realized through the entry of more productive firm, exit of the least productive firms and potentially the reallocation of resources between firms with different productive levels. The manufacturing sector and agricultural sector on the other hand fit in the active learning model by Ericson and Pakes (1995). Here, firms can improve their productivity level after entry by making investments, creating room for within firm productivity improvements.

Our results are in line with the so-called Baumol's disease, the belief that the inherent nature of services makes productivity improvements less likely than in the goods producing industries of the economy (Baumol, 1967). However, more recently, Triplett and Bosworth (2003) found substantial improvements in total factor productivity for the US services sector since 1995. van Ark et al. (2008) among others show that the accelaration in productivity growth for the services sector is more a US phenomena and that the slowdown in productivity growth in European countries relative to the US is mainly due to low productivity growth in the services sectors. As mentioned before, the number of studies performing a productivity growth decomposition for the services sectors remains limited. A notable exception is Foster et al. (2006) who analyze productivity growth in the US retail market for the period 19871997. They find aggregate labor productivity growth to be almost completely driven by the entry of more and exit of less productive establishments while within-firm productivity growth as well as the between component are close to zero.

Although the sample period differs between the current study and Foster et al. (2006), our findings can shed some light on the reasons behind the relative low performance of the retail sector in comparison to the US. ${ }^{12}$ Paricularly the negative within-firm productivity

\footnotetext{
${ }^{12}$ Tables 5 and 6 take the retail and wholesale sectors together. APG growth, within firm growth and
} 
growth and the negative contribution of entry stand out as the main differences with the retail sector in the US and UK (see for instance Baldwin and Gu, 2011) Baldwin and $\mathrm{Gu}$ (2011) hypothesize that these differences in performance can be traced back to product market regulation, which is much more stringent in continental Europe compared to the US, UK and Canada. Baugnet et al. (2009) present an analysis of the Belgian distribution sector, they use OECD indicators to infer the degree of regulation on the Belgian market, as well as in other countries. Similar to Baldwin and $\mathrm{Gu}$, Baugnet et al. point to the regulation as an important obstacle towards efficiency increases in the sector.

Next we classify the sectors into four categories, namely (1) High-Technology Industries, (2) Low-Technology Industries, (3) Knowledge Intensive Services and (4) Less-Knowledge Intensive Services. ${ }^{13}$ The results reported in Table 7 show that the knowledge intensive industries are the fastest growing sector in the economy and part of this growth is realized through productivity growth, but only through the reallocation of resources to higher value activities, indicating that the innovation level in these sectors is still fairly low. Surprisingly, productvity growth in the low-tech industries is higher than in the high-tech industries. Even within-firm productivity growth in the high tech sector is comparable to within firm productivity growth in the low tech industries. We can again compute the contributions of the different sectors to aggregate growth. The outcome is reported in Figure 4. Although the high-knowledge intesive services account for the largest part of economic growth, the low-tech manufacturing sectors are almost equally important in terms of APG, and the most important sectors for improvements in technical efficiency. Despite being the largest sector in terms of value added together with non-technological manufacturing, the low-knowledge intensive sectors only account for a relatively small part of economic growth and a tiny part of APG, caused by negative within-firm productivity growth.

reallocation for the retail sector alone is respectively $0.44,-1.02$ and $1.46 \%$. The results for the GrilichesRegev decomposition are - $0.39 \%$ (APG), $-1.02 \%$ (within), $0.51 \%$ (between), $-0.47 \%$ (entry) and $0.59 \%$ (exit).

${ }^{13} \mathrm{We}$ follow Eurostat and the OECD in the classification of these sectors. The precize classification of sectors can be found in the Appendix. 


\subsection{Firm Capabilities}

Over the past years, the number of firm level productivity studies has increased substantially. In this still growing body of literature several drivers of productivity have been identified, cf. Syverson (2011) for an overview. These studies can be related to the recent work of Sutton (2012) analyzing firm capabilities. Sutton considers the 'revealed' capability of a firm as its 'underlying capability', which consists of the set of elements of 'know-how' or 'working practices' held collectively by the group of individuals comprising the firm. Firms can acquire the necessary capabilities by investing in human capital (hiring skilled workers or investing in firm-specific human capital through training, cf. Konings and Vanormelingen, 2011) or, more indirectly, through spillovers resulting from its relationships with and interaction with foreign and domestic suppliers and competitors. We will bring in these capabilities in this subsection and determine how much they potentially contribute to aggregate productivity growth. We will focus mainly on two drivers of firm capabilities and will analyse human capital and international engagement of firms.

While most of the literature on human capital has looked at the relation between human capital and wages, the increasing availability of matched employer-employee datasets allows for the estimation of the impact of human capital on firm level productivity. For example, Ilmakunnass et al. (2004) find that productivity is increasing in worker's education and age. Konings and Vanormelingen (2011) show that firm-level productivity is increasing in the number of workers that received training. Concerning the relationship between international trade and productivity, it is well documented that the most productive firms tend to selfselect into international markets, but once they are internationally active they can realize productivity gains as well (cf. De Loecker (2007) for exporting, Halpern et al. (2011) for importing).

\subsubsection{Human Capital}

We look at two dimensions of human capital, namely at the accumulation of skills through the general education system and at skill acquisition through training provided by firms. In 
order to assess the contribution of the skills of the workers to aggregate productivity growth and its components, we classify firms into different categories according to the educational level or training level of their employees. First, we turn to the educational level. In the social balance sheet we observe - for firms that have to file the full annual account - the educational level of the inflow and outflow of employees for the period 1997-2007. To obtain a measure for the education level of the number of employees active in the firm we take the average share of medium high education and high education inflow in total inflow over all years, i.e. $s h_{i}^{M H}=\sum_{t}\left(I N_{i t}^{M}+I N_{i t}^{H}\right) / \sum_{t} I N_{i t}$ where $I N_{i t}^{M}$ and $I N_{i t}^{H}$ are respectively the inflow of medium-high education workers and high education workers for firm $i$ in year t. IN $N_{i t}$ is the total inflow of workers. After obtaining the share of medium-high and high education workers, we divide the firms in three categories, namely the first category - the (medium)-low education firms - comprises the firms for which the share of medium-high and high skilled workers is below the median computed over all firms. Similarly, the medium-high education category contains firms for which the share is higher than the medium and lower than the $75^{\text {th }}$ percentile. Finally, the high education category consists of the firms having a share of high and medium high workers in the top $25^{\text {th }}$ percentile.

This categorization results in each category being approximately equally important in terms of value added, namely $34 \%, 36 \%$ and $30 \%$ for the medium-low, medium-high and high education category respectively. The results for the Petrin-Levinsohn decomposition are reported in Table 8 and Figure 5. Productivity growth is on average highest in the high and medium high education categories while aggrgegate productivity growth is relatively low in the low-education category. The difference between the low-education category and the other categories even more pronounced when we turn to the technical efficiency (within) term. Here productivity growth is almost non-existent for the low-education category. Translated to the contributions of each category to the growth rates of value added and its different components, Figure 5 shows that within-firm productivity growth is mainly driven by firms having a share of highly educated workers above the median, while reallocation seems to 
take place mostly between firms with either low or high skill intensity.

Instead of defining human capital as the skills acquired through the general education system, the database allows us to take human capital built up throug firm provided training into account. More specifically we divide firms into training versus non-training categories where training firms are defined as having provided at least one period training to at least one employee. The results, reported in Figure 6, clearly show that firms that invest in training activities account for the lion share of productivity improvements within the firm and for a sizeable (though not larger than the share of value added accounted for by these firms, cf. Table 9) part of growth through reallocation. ${ }^{14}$

\subsubsection{Internationally Active Firms}

It has been well established that internationally active firms are more productive compared to non-internationally active firms, both theoretically (e.g. Melitz, 2003) and empirically (e.g. Bernard and Jensen, 1999). Internationalization can influence aggregate productivity growth through the reallocation of resources to more productive firms and/or through some learning-by-internationalizing effect where firms increase their productivity level more after entry in the international markets compared to firms only active on the domestic market. The first reallocation channel is for example the only source of productivity growth in the Melitz (2003) model, namely trade liberalization causes the least productive firms to exit the market and allows the most productive firms to expand. If our sample period is characterized by increasing trade liberalization or decreasing trade costs, the reallocation term should be the most important component of aggregate productivity growth.

We distingish between firms not involved in international trade, firms that are only importers, firms that are only exporters and firms engaged in both imports and exports, for trade in goods (Table 10) and for trade in services (Table 11). Firms are classified in the group they resided in most during the period considered. As can be seen from Table 10 and Table 11, two-way traders account for the bulk of total value added generated by firms

\footnotetext{
${ }^{14}$ The same results, both for the education level as training intensity, hold as well at the sector level (results available on request).
} 
in the private sector, even though they account for the minority of firms. These are the so-called Superstar Exporters (Mayer and Ottaviano, 2008) that dominate world trade and production.

The contribution of the different categories to aggregate productivity growth is depicted in Figure 7 and Figure 8. In line with expectations, aggregate productivity growth is larger for two-way traders compared to the no-traders. The difference however is mostly due to the within firm component, while the reallocation term is only slightly smaller for the no-traders. These results seem to indicate that theoretical models focusing solely on productivity gains through reallocation will understate the true productivity gains from liberalization. The group of firms that only import or export is clearly different for trade in goods than for trade in services, as evidenced by the reallocation and within terms in the tables. For trade in goods, there is a clear distinction between firms that only import and those that only export in terms of their share of total reallocation versus within-growth. For services, all trading firms contribute positively to both reallocation and within-firm productivity growth. Overall, this is explained by the fact that most firms that engage in services trade, are two-way traders on the goods market. ${ }^{15}$

\section{Conclusions}

We provide a thorough analysis of productivity growth in the Belgian private sector between 1997 and 2009. More precisely we determine the micro-level foundations of aggregate productivity growth following the decomposition methodology recently introduced by Petrin and Levinsohn (2012). The advantage of this method being that the different components add up to a measure of aggregate productivity growth that is close to macro definitions of aggregate productivity growth, i.e. changes in final demand that can not be explained by input changes. We find aggregate productivity growth to be equal to $1.46 \%$ on average over the sample period. The reallocation of resources from low-value activities to high-value ac-

\footnotetext{
${ }^{15}$ The same results hold as well at the sector level (results available on request).
} 
tivities is the main contributor to aggregate productivity growth, although improvements in firm-level technical efficiency play a role as well, especially in explaining fluctuations of aggregate productivity growth. A classic decomposition of aggregate productivity growth such as for example Griliches and Regev (1995), shows similar results. Turning to the sector level contributions to aggregate productivity growth, the results show that the Manufacturing, Agricultural and Telecommunication sectors realize highest productivity growth. Aggregate productivity growth is low in the services sectors, especially so for within-firm productivity growth.

Dividing the sample into different categories according to the firm capabilities shows that productivity growth is mainly realized by firms having high levels of human capital obtained either through the general education system or through firm provided training - and by firms that engage in international trade. Firms active in non-trading sectors (Hotels and restaurants, Construction), in spite of their importance for overall employment, contribute very little to overall productivity growth realized in Belgium between 1997 and 2009. 


\section{References}

Baily, Martin Neil, Hulten, Charles, Campbell, David, Bresnahan, Timothy, \& Caves, Richard E. (1992). Productivity Dynamics in Manufacturing Plants. Brookings Papers on Economic Activity. Microeconomics, 1992, 187-267.

Baldwin, John.R. and Wulong Gu (2011). Firm Dynamics and Productivity Growth: a Comparison of the Retail Trade and Manufacturing Sectors. Industrial and Corporate Change, 20(2), 367-395.

Baugnet, V., D. Cornille, E. Dhyne and B. Robert (2009). Regulering en concurrentie in de Belgische distributiesector. Economisch tijdschrift 2009/17.

Baumol, William J. (1967). Macroeconomics of Unbalanced Growth: The Anatomy of Urban Crises. American Economic Review 57(3): 415-26.

Bernard, Andrew B., \& Jensen, J.Bradford. (1999). Exceptional exporter performance: Cause, effect or both? Journal of International Economics, 47(1), 1-25.

Bernard, A.B., Jensen J. Bradford, Stephen J. Redding and Peter K. Schott (2012). The Empirics of Firm Heterogeneity in International Trade. The Annual Review, 4, 283-313.

Conway, P. and G. Nicoletta (2006). Product Market Regulation in the Non-Manufacturing Sectors of OECD Countries: Measurements and Highlights. OECD Economics Department Working Paper, 530.

Corry, D, Valero, A. and Van Reenen, J. (2011). UK Economic Performance Since 1997: Growth, Productivity and Jobs. Special Paper No. 24, Centre for Economic Performance, London School of Economics.

De Loecker, Jan. (2007). Do Exports Generate Higher Productivity? Evidence from Slovenia. Journal of International Economics, 73(1), 69-98. 
Domar, E. D. (1961). On the Measurement of Technological Change. The Economic Journal, 71(284), 709-729.

Ericson, Richard and Ariel Pakes (1995). Markov-Perfect Industry Dynamics: A Framework for Empirical Work. The Review of Economic Studies, 62(1), 53-82.

Foster, Lucia, Haltiwanger, John, \& Krizan, C.J. (2001). Aggregate Productivity Growth: Lessons from Microeconomic Evidence. In D. Edward, M. Harper \& C. Hulten (Eds.), New Developments in Productivity Analysis (pp. 303-363). Chicago: University of Chicago Press.

Foster, L., J. Haltiwanger and C.J. Krizan (2002). The Link Between Aggregate and Micro Productivity Growth: Evidence from Retail Trade. NBER Working Paper 9120.

Foster, Lucia, Haltiwanger, John, \& Krizan, C. J. (2006). Market Selection, Reallocation, and Restructuring in the US Retail Trade Sector in the 1990s. Review of Economics \& Statistics, 88(4), 748-758.

Griliches, Zvi, \& Regev, Haim. (1995). Firm productivity in Israeli industry 1979-1988. Journal of Econometrics, 65(1), 175-203.

Hallward-Driemeier, M. and B. Rijkers (2013). "Do crises catalyze creative destruction? Firm-level evidence from Indonesia." Review of Economics and Statistics, forthcoming.

Halpern, László, Koren, Miklós \& Szeidl, Adam (2011). Imported Inputs and Productivity. CeFiG Working Papers 8, Center for Firms in the Global Economy.

Ilmakunnas, Pekka, Mika Maliranta, and Jari Vainiomäki. (2004). "The Roles of Employer and Employee Characteristics for Plant Productivity." Journal of Productivity Analysis, 21(3): 249-276.

Jones, Charles I., \& Romer, Paul M. (2010). The New Kaldor Facts: Ideas, Institutions, Population, and Human Capital. American Economic Journal: Macroeconomics, 2(1), 224245 
Jovanovic, Boyan. (1982). Selection and the Evolution of Industry. Econometrica, 50(3), 649-670.

Konings, J. and Vanormelingen, S. (2011). The Impact of Training on Firm Level Productivity and Wages: Evidence from Belgium, KU Leuven.

Mayer, T. and Ottaviano, G. (2008). The Happy Few: the Internationalization of European firms: New Facts Based on Firm Level Evidence. Intereconomics, May/June.

Melitz, Marc J. (2003). The Impact of Trade on Intra-Industry Reallocations and Aggregate Industry Productivity. Econometrica, 71(6), 1695-1725.

Olley, G. Steven, \& Pakes, Ariel. (1996). The Dynamics of Productivity in the Telecommunications Equipment Industry. Econometrica, 64(6), 1263-1297.

Petrin, Amil, White, Kirk, \& Reiter, Jerome P. (2011). The Impact of Plant-Level Resource Reallocations and Technical Progress on U.S. Macroeconomic Growth. Review of Economic Dynamics, 14, 3-26.

Petrin, Amil, \& Levinsohn, James. (2012). Measuring Aggregate Productivity Growth Using Plant-Level Data. RAND Journal of Economics, 43(4), 705-725.

Sutton, J. (2012). Competing in capabilities. The Globalization Process. Oxford University Press

Syverson, Chad. (2011). What Determines Productivity? Journal of Economic Literature, 49(2), 326-365.

Triplett, Jack E. \& Bosworth, Barry P. (2003). Productivity measurement issues in services industries: "Baumol's disease" has been cured, Economic Policy Review, Federal Reserve Bank of New York, September, 23-33. 
van Ark, Bart, O’Mahoney, Mary, \& Timmer, Marcel P. (2008). The Productivity Gap between Europe and the United States: Trends and Causes. Journal of Economic Perspectives, 22(1), 25-44.

Wooldridge, Jeffrey M. (2009). On Estimating Firm-Level Production Functions Using Proxy Variables to Control for Unobservables. Economics Letters, 104(3), 112-114. 


\section{$\begin{array}{ll}7 & \text { Tables }\end{array}$}

Table 1: Summaries

\begin{tabular}{l|cccc}
\hline \hline & \multicolumn{2}{|c}{ All Firms } & \multicolumn{2}{c}{ large Firms } \\
& Mean & S.D. & Mean & S.D. \\
\hline Employment & 15 & 225 & 102 & 687 \\
Real Value Added (X1000€) & 1,084 & 15,639 & 7,630 & 47,137 \\
Real turnover (X1000€) & \multicolumn{2}{c}{-} & 40,925 & 311,597 \\
Labor prod (X1000€) & 95 & 857 & 159 & 2,440 \\
$\alpha_{l}$ & 0.62 & 0.30 & 0.74 & 0.34 \\
$\alpha_{k}$ & 0.20 & 0.19 & 0.15 & 0.19 \\
$\beta_{l}$ & \multicolumn{2}{|c}{-} & 0.22 & 0.19 \\
$\beta_{m}$ & \multicolumn{2}{|c}{-} & 0.69 & 0.22 \\
$\beta_{k}$ & \multicolumn{2}{|c}{-} & 0.05 & 0.10 \\
\hline Nr. Firms & 228,374 & 23,030 \\
Nr. Observations & $1,553,480$ & \multicolumn{2}{c}{161,644} \\
\hline \hline
\end{tabular}


Table 2: Value Added and Aggregate Productivity Growth

\begin{tabular}{lcccc|c}
\hline \hline Year & Value added & Labor & Capital & $A P G^{P L}$ & $A P G^{G R}$ \\
\hline 1998 & $4.25 \%$ & $2.36 \%$ & $0.82 \%$ & $1.06 \%$ & $0.75 \%$ \\
1999 & $3.50 \%$ & $0.40 \%$ & $0.28 \%$ & $2.82 \%$ & $1.62 \%$ \\
2000 & $3.12 \%$ & $0.61 \%$ & $0.31 \%$ & $2.21 \%$ & $1.99 \%$ \\
2001 & $0.32 \%$ & $0.78 \%$ & $0.07 \%$ & $-0.53 \%$ & $-1.19 \%$ \\
2002 & $0.47 \%$ & $-0.98 \%$ & $-0.13 \%$ & $1.58 \%$ & $0.99 \%$ \\
2003 & $1.93 \%$ & $-0.90 \%$ & $0.00 \%$ & $2.83 \%$ & $3.24 \%$ \\
2004 & $2.58 \%$ & $-0.03 \%$ & $0.20 \%$ & $2.40 \%$ & $3.16 \%$ \\
2005 & $0.84 \%$ & $-0.04 \%$ & $-0.75 \%$ & $1.62 \%$ & $-1.36 \%$ \\
2006 & $1.31 \%$ & $0.54 \%$ & $-0.11 \%$ & $0.87 \%$ & $0.35 \%$ \\
2007 & $4.38 \%$ & $1.04 \%$ & $0.36 \%$ & $2.99 \%$ & $1.80 \%$ \\
2008 & $-0.13 \%$ & $0.29 \%$ & $0.39 \%$ & $-0.81 \%$ & $-0.20 \%$ \\
2009 & $-2.44 \%$ & $-2.59 \%$ & $-0.32 \%$ & $0.46 \%$ & $2.17 \%$ \\
\hline Average & $1.68 \%$ & $0.12 \%$ & $0.09 \%$ & $1.46 \%$ & $1.11 \%$ \\
\hline \hline
\end{tabular}

Table 3: Decomposition Aggregate Productivity Growth PL

\begin{tabular}{lcccccc}
\hline \hline Year & APG & Within & Reall & & & \\
& & & & Labor & Capital & Fixed Cost \\
\hline 1998 & $1.06 \%$ & $0.38 \%$ & $0.69 \%$ & $1.30 \%$ & $-0.60 \%$ & $0.00 \%$ \\
1999 & $2.82 \%$ & $1.75 \%$ & $1.07 \%$ & $1.08 \%$ & $-0.09 \%$ & $0.08 \%$ \\
2000 & $2.21 \%$ & $1.09 \%$ & $1.12 \%$ & $0.96 \%$ & $-0.05 \%$ & $0.20 \%$ \\
2001 & $-0.53 \%$ & $-1.85 \%$ & $1.33 \%$ & $1.33 \%$ & $0.36 \%$ & $-0.37 \%$ \\
2002 & $1.58 \%$ & $0.62 \%$ & $0.96 \%$ & $0.14 \%$ & $0.65 \%$ & $0.18 \%$ \\
2003 & $2.83 \%$ & $1.13 \%$ & $1.70 \%$ & $1.17 \%$ & $0.50 \%$ & $0.03 \%$ \\
2004 & $2.40 \%$ & $0.58 \%$ & $1.82 \%$ & $1.04 \%$ & $0.18 \%$ & $0.60 \%$ \\
2005 & $1.62 \%$ & $-0.57 \%$ & $2.20 \%$ & $1.12 \%$ & $1.23 \%$ & $-0.15 \%$ \\
2006 & $0.87 \%$ & $0.56 \%$ & $0.31 \%$ & $0.67 \%$ & $0.23 \%$ & $-0.58 \%$ \\
2007 & $2.99 \%$ & $1.33 \%$ & $1.66 \%$ & $0.94 \%$ & $0.13 \%$ & $0.59 \%$ \\
2008 & $-0.81 \%$ & $-1.42 \%$ & $0.61 \%$ & $0.72 \%$ & $0.04 \%$ & $0.17 \%$ \\
2009 & $0.46 \%$ & $-1.06 \%$ & $1.53 \%$ & $-0.06 \%$ & $1.42 \%$ & $0.05 \%$ \\
\hline Average & $1.46 \%$ & $0.21 \%$ & $1.25 \%$ & $0.87 \%$ & $0.33 \%$ & $0.05 \%$ \\
St.Dev. & $1.28 \%$ & $1.16 \%$ & $0.56 \%$ & $0.44 \%$ & $0.56 \%$ & $0.34 \%$ \\
\hline \hline
\end{tabular}

Petrin-Levinsohn decomposition aggregate productivity growth. Translog production function estimated using Wooldridge (2009). 
Table 4: Decomposition Aggregate Productivity Growth Griliches-Regev

\begin{tabular}{lccccc}
\hline \hline Year & APG & Within & Between & Entry & Exit \\
\hline 1998 & $0.75 \%$ & $0.41 \%$ & $-0.30 \%$ & $0.34 \%$ & $0.31 \%$ \\
1999 & $1.62 \%$ & $1.72 \%$ & $0.21 \%$ & $0.41 \%$ & $-0.72 \%$ \\
2000 & $1.99 \%$ & $1.11 \%$ & $0.55 \%$ & $0.25 \%$ & $0.09 \%$ \\
2001 & $-1.19 \%$ & $-1.83 \%$ & $0.04 \%$ & $-0.06 \%$ & $0.66 \%$ \\
2002 & $0.99 \%$ & $0.70 \%$ & $0.21 \%$ & $0.36 \%$ & $-0.29 \%$ \\
2003 & $3.24 \%$ & $1.13 \%$ & $1.06 \%$ & $0.38 \%$ & $0.67 \%$ \\
2004 & $3.16 \%$ & $0.51 \%$ & $-0.17 \%$ & $2.39 \%$ & $0.43 \%$ \\
2005 & $-1.36 \%$ & $-0.51 \%$ & $-1.55 \%$ & $0.27 \%$ & $0.42 \%$ \\
2006 & $0.35 \%$ & $0.59 \%$ & $0.17 \%$ & $0.07 \%$ & $-0.49 \%$ \\
2007 & $1.80 \%$ & $1.44 \%$ & $-0.64 \%$ & $0.29 \%$ & $0.72 \%$ \\
2008 & $-0.20 \%$ & $-1.15 \%$ & $0.35 \%$ & $-0.28 \%$ & $0.88 \%$ \\
2009 & $2.17 \%$ & $-0.92 \%$ & $1.74 \%$ & $0.95 \%$ & $0.39 \%$ \\
\hline Average & $1.11 \%$ & $0.27 \%$ & $0.14 \%$ & $0.45 \%$ & $0.26 \%$ \\
\hline \hline
\end{tabular}

Griliches-Regev decomposition aggregate productivity growth. Translog production function estimated using Wooldridge (2009). Aggregate productivity growth and components are weighted averages of sector level productivity growth and components.

Table 5: Aggregate Productivity Growth per Sector

\begin{tabular}{lcccccc}
\hline \hline & Value Added & Labor & Capital & APG & & \\
& & & & & Within & Reall \\
\hline ABC Agriculture, Mining & $6.70 \%$ & $0.67 \%$ & $0.70 \%$ & $5.33 \%$ & $4.55 \%$ & $0.77 \%$ \\
D Manufacturing & $0.09 \%$ & $-1.34 \%$ & $-0.25 \%$ & $1.69 \%$ & $1.11 \%$ & $0.58 \%$ \\
E Utilities & $2.81 \%$ & $1.38 \%$ & $0.43 \%$ & $1.01 \%$ & $-3.61 \%$ & $4.62 \%$ \\
F Construction & $2.07 \%$ & $0.92 \%$ & $0.46 \%$ & $0.69 \%$ & $-0.87 \%$ & $1.56 \%$ \\
G Wholesale and Retail & $1.38 \%$ & $0.59 \%$ & $0.20 \%$ & $0.58 \%$ & $-0.73 \%$ & $1.32 \%$ \\
H Hotels and Restaurants & $0.63 \%$ & $1.27 \%$ & $0.01 \%$ & $-0.65 \%$ & $-1.40 \%$ & $0.75 \%$ \\
I Transport and Communication & $2.15 \%$ & $-0.54 \%$ & $-0.03 \%$ & $2.72 \%$ & $1.20 \%$ & $1.52 \%$ \\
K Business Services & $4.27 \%$ & $2.60 \%$ & $0.52 \%$ & $1.15 \%$ & $-0.30 \%$ & $1.45 \%$ \\
\hline \hline Petrin-Levinsohn decomposition aggregate productivity growth. Translog production function estimated using Wooldridge \\
(2009).
\end{tabular}

Table 6: Aggregate Productivity Growth per Sector, Griliches-Regev

\begin{tabular}{lccccc}
\hline \hline Year & APG & Within & Between & Entry & Exit \\
\hline ABC Agriculture, Mining & $4.46 \%$ & $4.58 \%$ & $0.28 \%$ & $-0.51 \%$ & $0.12 \%$ \\
D Manufacturing & $1.78 \%$ & $1.23 \%$ & $0.15 \%$ & $-0.28 \%$ & $0.68 \%$ \\
F Construction & $0.42 \%$ & $-0.87 \%$ & $-0.80 \%$ & $2.56 \%$ & $-0.46 \%$ \\
G Wholesale and Retail & $-0.06 \%$ & $-0.72 \%$ & $0.32 \%$ & $-0.04 \%$ & $0.39 \%$ \\
H Hotels and Restaurants & $-1.80 \%$ & $-1.40 \%$ & $0.33 \%$ & $-1.08 \%$ & $0.35 \%$ \\
I Transport and Communication & $1.63 \%$ & $1.26 \%$ & $-0.08 \%$ & $-0.34 \%$ & $0.78 \%$ \\
K Business Services & $0.85 \%$ & $-0.28 \%$ & $-1.06 \%$ & $3.07 \%$ & $-0.88 \%$ \\
\hline \hline
\end{tabular}


Table 7: APG in High Tech Industries / Knowledge Intensive Services

\begin{tabular}{lcccccccc|c}
\hline \hline Year & Val. Add. & Labor & Capital & APG & Within & Reall & & & \\
$\cdot$ & & & & & & & Labor & Capital & VA Share \\
\hline Low Tech Ind. & $1.18 \%$ & $-0.50 \%$ & $0.01 \%$ & $1.67 \%$ & $0.59 \%$ & $1.08 \%$ & $0.69 \%$ & $0.37 \%$ & $31.50 \%$ \\
High-tech Ind. & $-0.47 \%$ & $-1.46 \%$ & $-0.28 \%$ & $1.27 \%$ & $0.70 \%$ & $0.57 \%$ & $0.58 \%$ & $0.56 \%$ & $14.00 \%$ \\
Low-KIS Serv. & $1.69 \%$ & $0.66 \%$ & $0.23 \%$ & $0.79 \%$ & $-0.22 \%$ & $1.01 \%$ & $0.81 \%$ & $0.15 \%$ & $36.70 \%$ \\
High-KIS Serv. & $4.41 \%$ & $1.41 \%$ & $0.27 \%$ & $2.74 \%$ & $-0.01 \%$ & $2.75 \%$ & $1.53 \%$ & $0.46 \%$ & $17.80 \%$ \\
\hline \hline
\end{tabular}

Table 8: Firm Capabilities: Education

\begin{tabular}{lcccccccc|c}
\hline \hline Year & Val. Add. & Labor & Capital & APG & Within & Reall. & & \\
& & & & & & & Labor & Capital & VA Share \\
\hline (Medium-)Low-educ. & $1.79 \%$ & $0.56 \%$ & $0.04 \%$ & $1.19 \%$ & $0.23 \%$ & $0.96 \%$ & $0.93 \%$ & $0.10 \%$ & $33.70 \%$ \\
Medium-high-educ. & $1.86 \%$ & $-0.04 \%$ & $-0.12 \%$ & $2.01 \%$ & $1.18 \%$ & $0.83 \%$ & $0.63 \%$ & $0.37 \%$ & $36.00 \%$ \\
High-skilled & $2.91 \%$ & $0.20 \%$ & $0.14 \%$ & $2.57 \%$ & $0.72 \%$ & $1.85 \%$ & $1.10 \%$ & $0.45 \%$ & $30.30 \%$ \\
\hline \hline
\end{tabular}

Petrin-Levinsohn decomposition aggregate productivity growth. Translog production function estimated using Wooldridge (2009). Sample

restricted to firms reporting full annual accounts.

Table 9: Firm Capabilities: Formal Training Actitvities

\begin{tabular}{lcccccccc|c}
\hline \hline Year & Val. Add. & Labor & Capital & APG & Within & Reall. & & \\
& & & & & & & Labor & Capital & VA Share \\
\hline No training & $2.31 \%$ & $0.49 \%$ & $0.33 \%$ & $1.49 \%$ & $-0.17 \%$ & $1.66 \%$ & $1.24 \%$ & $0.23 \%$ & $38.33 \%$ \\
Training & $2.24 \%$ & $0.30 \%$ & $-0.04 \%$ & $1.98 \%$ & $0.91 \%$ & $1.07 \%$ & $0.81 \%$ & $0.27 \%$ & $61.67 \%$ \\
\hline \hline
\end{tabular}

Petrin-Levinsohn decomposition aggregate productivity growth. Translog production function estimated using Wooldridge (2009). Full sample of firms, time period 1998-2007 (change in definition of training starting 2008)..

Table 10: Firm Capabilities: International trade in goods

\begin{tabular}{lcccccccc|c}
\hline \hline Year & Val. Add. & Labor & Capital & APG & Within & Reall. & & \\
& & & & & & & Labor & Capital & VA Share \\
\hline No-traders & $2.51 \%$ & $1.30 \%$ & $0.37 \%$ & $0.83 \%$ & $-0.46 \%$ & $1.29 \%$ & $1.12 \%$ & $0.00 \%$ & $31.97 \%$ \\
Only importers & $3.51 \%$ & $1.98 \%$ & $0.09 \%$ & $1.44 \%$ & $-1.12 \%$ & $2.56 \%$ & $1.87 \%$ & $0.38 \%$ & $9.60 \%$ \\
Only exporters & $0.62 \%$ & $-0.08 \%$ & $0.36 \%$ & $0.34 \%$ & $0.28 \%$ & $0.05 \%$ & $0.60 \%$ & $-0.19 \%$ & $2.27 \%$ \\
Two-way traders & $0.94 \%$ & $-0.84 \%$ & $-0.07 \%$ & $1.85 \%$ & $0.80 \%$ & $1.05 \%$ & $0.56 \%$ & $0.53 \%$ & $56.16 \%$ \\
\hline \hline
\end{tabular}

Petrin-Levinsohn decomposition aggregate productivity growth. Translog production function estimated using Wooldridge (2009).

Table 11: Firm Capabilities: International Trade in Services

\begin{tabular}{lcccccccc|c}
\hline \hline Year & Val. Add. & Labor & Capital & APG & Within & Reall. & & \\
& & & & & & & Labor & Capital & VA Share \\
\hline no-trader & $2.29 \%$ & $0.85 \%$ & $0.35 \%$ & $1.10 \%$ & $-0.04 \%$ & $1.15 \%$ & $1.15 \%$ & $-0.03 \%$ & $47.88 \%$ \\
only M & $2.17 \%$ & $0.28 \%$ & $-0.12 \%$ & $2.02 \%$ & $0.62 \%$ & $1.40 \%$ & $0.89 \%$ & $0.07 \%$ & $14.46 \%$ \\
only X & $3.43 \%$ & $0.92 \%$ & $0.16 \%$ & $2.34 \%$ & $0.95 \%$ & $1.39 \%$ & $1.48 \%$ & $0.30 \%$ & $2.80 \%$ \\
two-way & $1.77 \%$ & $-0.55 \%$ & $-0.15 \%$ & $2.47 \%$ & $0.84 \%$ & $1.62 \%$ & $0.84 \%$ & $0.77 \%$ & $34.86 \%$ \\
\hline \hline \multicolumn{2}{l}{ Petrin-Levinsohn decomposition aggregate productivity growth. Translog production function estimated using Wooldridge (2009). }
\end{tabular}




\section{Figures}

Figure 1: Value Added and GDP Growth

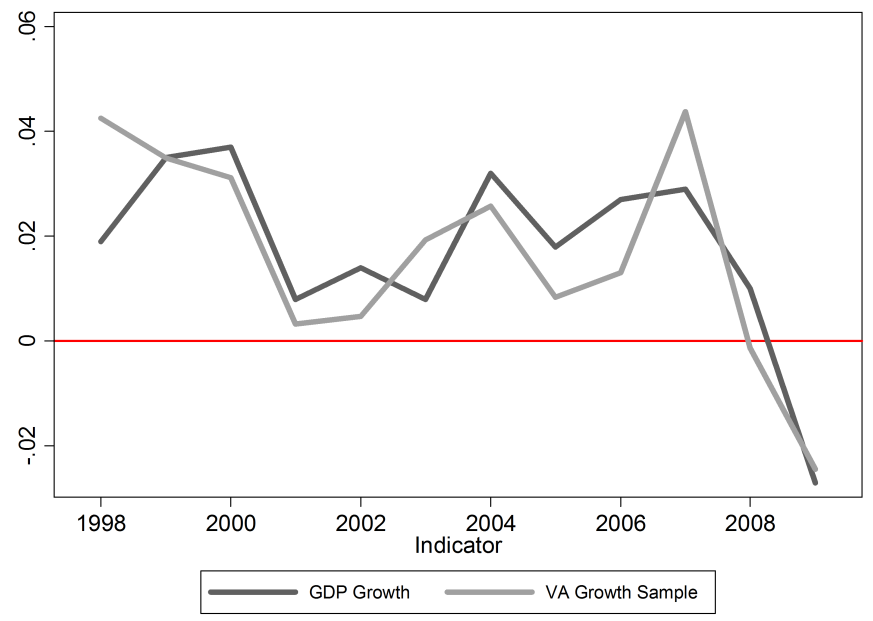

Figure 2: Comparing Different Definitions Total Factor Productivity Growth

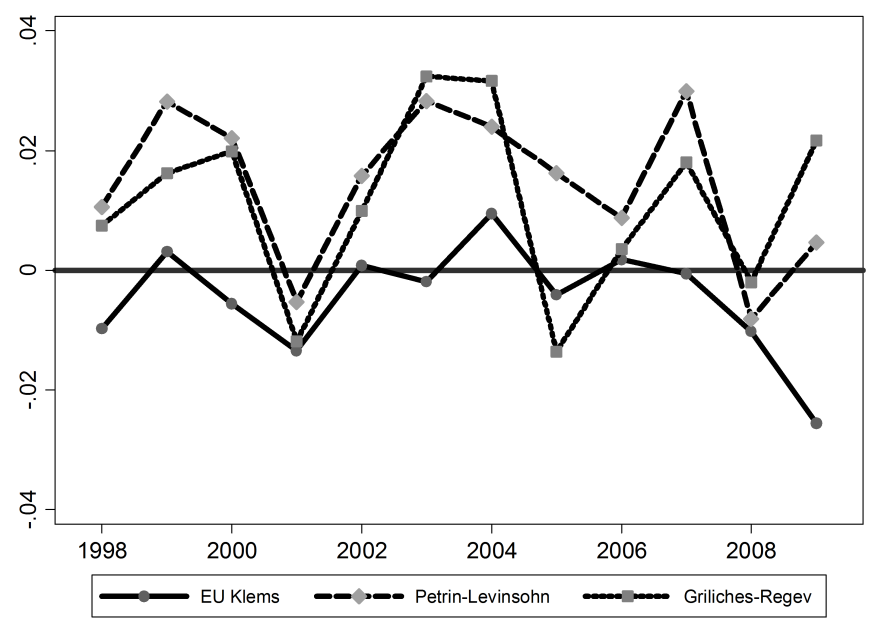


Figure 3: Contributions of Different Sectors to Aggregate Productivity Growth

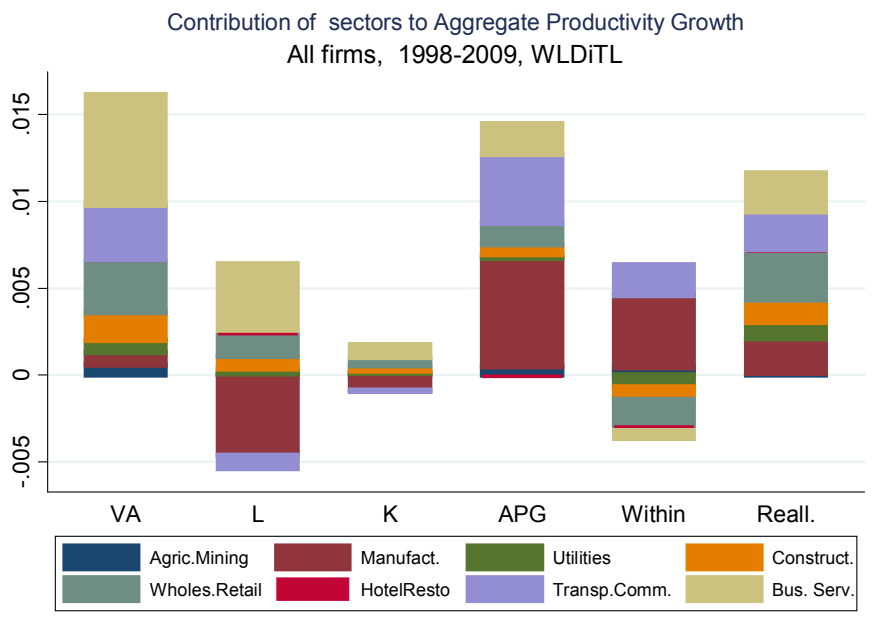

Figure 4: Contribution of Sectors to Aggregate Productivity Growth: Technology and Knowledge Intensity

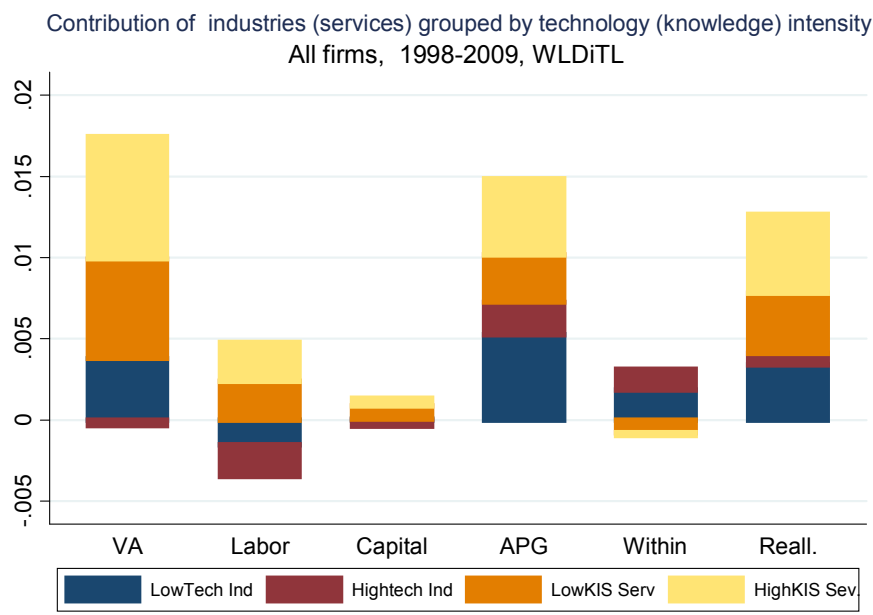


Figure 5: Firm Capabilities: Average Skill Intensity

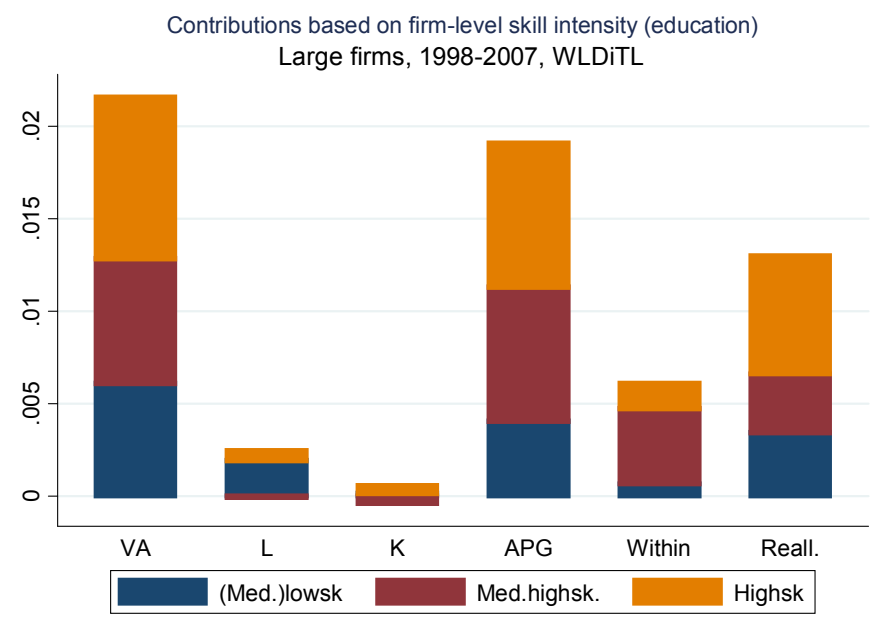

Figure 6: Firm Capabilities: Formal Training Activities

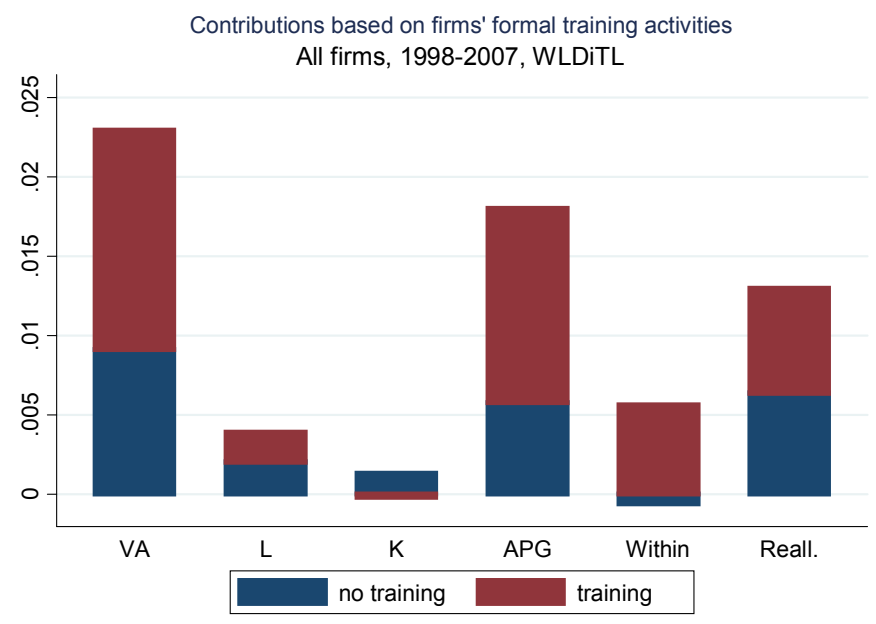


Figure 7: Firm Capabilities: International Trade in Goods

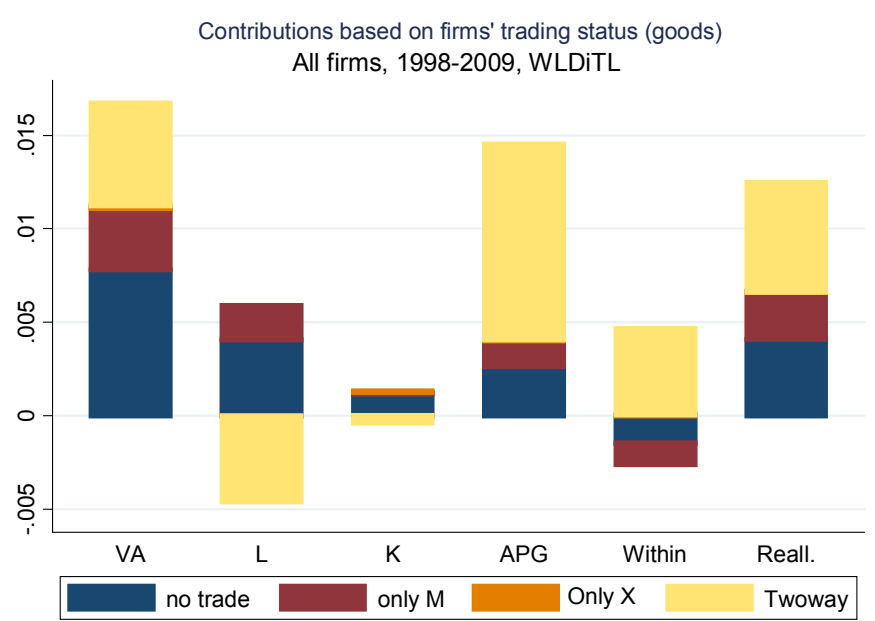

Figure 8: Firm Capabilities: International Trade in Services

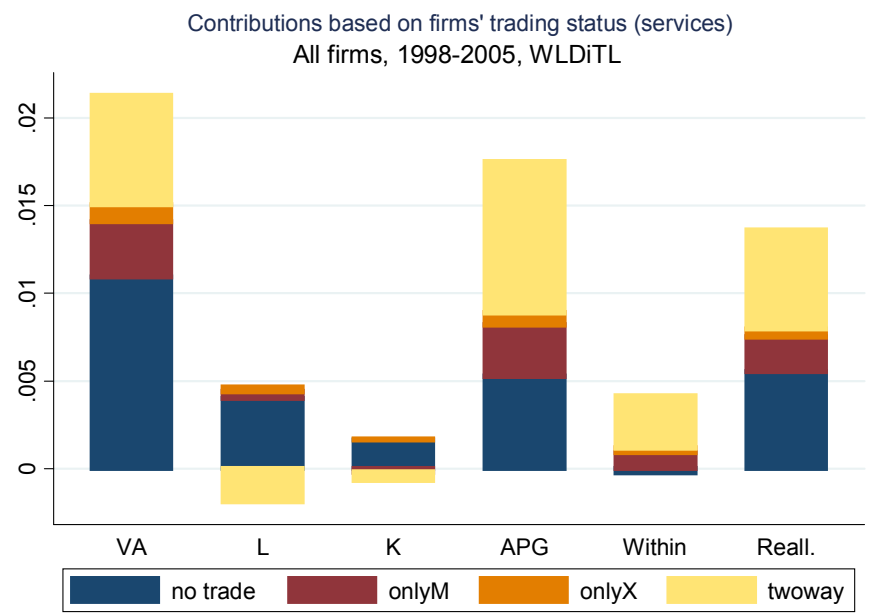




\section{Appendix}

\section{A Sector Classification}

This appendix provides the details of the sector classification into high-tech industries, lowtech industries, skill intensive services and less-skill intensive services. For the classification of the manufacturing sector into high-technology and low-technology we rely on the OECD classification where we take the high and medium high technology sectors as high technology sectors and the low and medium-low tech industries as the low technology industries (cf. Table A.1). Furthermore we include in the low tech industries the Agricultural Sector, Mining and Quarrying, Recycling, Utilities and Construction.

To classify the services sectors we follow the Eurostat classification. ${ }^{16}$, cf. Table A.2.

\footnotetext{
${ }^{16}$ The newest Eurostat classification is at the NACE rev. 2 level and we manually concord the NACE rev. 1 codes with this classification.
} 


\section{Table A.1: OECD Classification High Tech Sectors}

\begin{tabular}{lcc}
\hline \hline & NACE Revision 1.1 & ISIC Revision 2 \\
\hline High-technology & 35.3 & \\
1. Aerospace & 30 & 3845 \\
2. Computers, office machinery & 32 & 3825 \\
3. Electronics-communications & 24.4 & 3832 \\
4. Pharmaceuticals & 33 & 3522 \\
5. Scientific instruments & & 385 \\
Medium-high-technology & 34 & \\
6. Motor vehicles & 31 & 3843 \\
7. Electrical machinery & $24-24.4$ & $383-3832$ \\
8. Chemicals & $35.2+35.4+35.5$ & $351+352-3522$ \\
9. Other transport equipment & 29 & $382-3825$ \\
10.Non-electrical machinery & & \\
Medium-low-technology & 25 & $355+356$ \\
11. Rubber and plastic products & 35.1 & 3841 \\
12. Shipbuilding & 36.2 through 36.6 & 39 \\
13. Other manufacturing & $27.4+27.53 / 54$ & 362 \\
14. Non-ferrous metals & 26 & 381 \\
15. Non-metallic mineral products & 28 & $351+354$ \\
16. Fabricated metal products & 23 & 371 \\
17. Petroleum refining & & \\
18. Ferrous metals & $21+22$ & 34 \\
Low-technology & 17 through 19 & 32 \\
19. Paper printing & $20+36.1$ & 33 \\
20. Textile and clothing & & \\
21. Food, beverages, and tobacco & through $27.3+27.51 / 52$ & \\
22. Wood and furniture & & \\
\hline \hline
\end{tabular}

Table A.2: Eurostat Classification Knowledge Intensive Services

\begin{tabular}{cc}
\hline \hline Description & NACE Rev 1 Code \\
Knowledge Intensive Sectors & 60 to 61 \\
Water Transport, Air Transport & 642 \\
Telecommunications & 72 \\
Computer Services & 73 \\
Research \& Development & 65 to 67 \\
Financial and Insurance Activities & $741-746$ \\
Business Services (excl. cleaning and other business services) & \\
Less-Knowledge Intensive Sectors & 50 to 52 \\
Wholesale and Retail & 60 \\
Land Transport & 63 \\
Postal Services & 641 \\
Supporting Transportation Services; Travel Agencies & 55 \\
Accommodation and Food Service & 71 \\
Rental and Leasing & 70 \\
Real Estate & 747 to 748 \\
\hline \hline
\end{tabular}




\section{B Construction of the Real Capital Stock}

We have information on the different types of tangible fixed assets (buildings, machinery and equipment, transport equipment) and take as the initial capital stock of a firm the book value of the capital stock in the year that the firm enters the industry/sample, deflated by the appropriate economy-wide gross fixed capital formation price index. (for example we use the price deflator for non-residential housing to deflate the book value of buildings). To construct the real capital stock for the subsequent years, we first compute nominal investment by combining information on the book value of tangibles and depreciation, i.e.: $I_{t}=K_{i t}+$ $D_{i t}-K_{i t-1}$. We deflate nominal investment $I_{i t}$ and construct the real capital stock as $\widetilde{K}_{i t}=\left(\widetilde{K}_{i t-1}+\widetilde{I}_{i t}\right)\left(1-\delta_{i t}\right)$ where $\widetilde{K}_{i t}$ and $\widetilde{I}_{i t}$ represent real capital and investment respectively. $\delta_{i t}$ is the depreciation rate of firm defined as $\delta_{i t}=D_{i t} /\left(K_{i t}+D_{i t}\right)$.

\section{Robustness Checks}

\section{C.1 Number of Hours as Labor Input}

Table C.1: Petrin-Levinsohn Decomposition Hours as Labor Input

\begin{tabular}{lcccccccc}
\hline \hline Year & Val. Ad. & Labor & Capital & APG & Within & Reallocation & \\
& & & & & & & Labor & Capital \\
\hline 998 & $2.45 \%$ & $-0.52 \%$ & $-0.30 \%$ & $3.27 \%$ & $1.14 \%$ & $2.13 \%$ & $2.71 \%$ & $-0.04 \%$ \\
1999 & $3.71 \%$ & $1.13 \%$ & $0.39 \%$ & $2.18 \%$ & $1.87 \%$ & $0.32 \%$ & $0.81 \%$ & $-0.12 \%$ \\
2000 & $4.16 \%$ & $1.34 \%$ & $1.11 \%$ & $1.71 \%$ & $-0.22 \%$ & $1.93 \%$ & $0.56 \%$ & $-0.88 \%$ \\
2001 & $0.65 \%$ & $-0.30 \%$ & $0.11 \%$ & $0.83 \%$ & $-0.49 \%$ & $1.32 \%$ & $1.56 \%$ & $0.10 \%$ \\
2002 & $0.89 \%$ & $-0.82 \%$ & $-0.02 \%$ & $1.74 \%$ & $0.81 \%$ & $0.93 \%$ & $0.31 \%$ & $0.70 \%$ \\
2003 & $1.62 \%$ & $-1.18 \%$ & $0.04 \%$ & $2.75 \%$ & $2.12 \%$ & $0.64 \%$ & $1.10 \%$ & $0.29 \%$ \\
2004 & $2.60 \%$ & $0.21 \%$ & $0.19 \%$ & $2.20 \%$ & $0.85 \%$ & $1.35 \%$ & $1.41 \%$ & $0.10 \%$ \\
2005 & $0.67 \%$ & $-0.92 \%$ & $-0.77 \%$ & $2.35 \%$ & $0.33 \%$ & $2.02 \%$ & $0.98 \%$ & $1.38 \%$ \\
2006 & $1.22 \%$ & $0.48 \%$ & $-0.14 \%$ & $0.89 \%$ & $0.69 \%$ & $0.20 \%$ & $0.58 \%$ & $0.32 \%$ \\
2007 & $4.90 \%$ & $1.22 \%$ & $0.39 \%$ & $3.28 \%$ & $2.33 \%$ & $0.96 \%$ & $0.91 \%$ & $-0.10 \%$ \\
2008 & $0.14 \%$ & $0.55 \%$ & $0.41 \%$ & $-0.82 \%$ & $-1.39 \%$ & $0.57 \%$ & $0.86 \%$ & $-0.10 \%$ \\
2009 & $-2.55 \%$ & $-3.95 \%$ & $-0.26 \%$ & $1.65 \%$ & $1.43 \%$ & $0.23 \%$ & $-0.68 \%$ & $1.16 \%$ \\
\hline Average & $1.70 \%$ & $-0.23 \%$ & $0.10 \%$ & $1.84 \%$ & $0.79 \%$ & $1.05 \%$ & $0.92 \%$ & $0.23 \%$ \\
\hline \hline
\end{tabular}

Petrin-Levinsohn decomposition aggregate productivity growth. Translog production function estimated using Wooldridge (2009). 


\section{C.2 Book Value of Tangible Fixed Assets}

Table C.2: Petrin-Levinsohn Decomposition Book Value Tangible Fixed Assets

\begin{tabular}{lcccccccc} 
Year & Val. Ad. & Labor & Capital & APG & Within & Reall. & \\
& & & & & & & Labor & Capital \\
\hline 1998 & $4.36 \%$ & $2.38 \%$ & $0.68 \%$ & $1.29 \%$ & $0.40 \%$ & $0.89 \%$ & $1.34 \%$ & $-0.50 \%$ \\
1999 & $3.59 \%$ & $0.50 \%$ & $0.10 \%$ & $3.00 \%$ & $1.59 \%$ & $1.41 \%$ & $1.03 \%$ & $0.14 \%$ \\
2000 & $3.42 \%$ & $0.82 \%$ & $0.17 \%$ & $2.44 \%$ & $1.36 \%$ & $1.07 \%$ & $1.09 \%$ & $0.12 \%$ \\
2001 & $0.88 \%$ & $1.13 \%$ & $0.34 \%$ & $-0.59 \%$ & $-1.83 \%$ & $1.24 \%$ & $1.39 \%$ & $0.04 \%$ \\
2002 & $0.81 \%$ & $-0.86 \%$ & $0.26 \%$ & $1.41 \%$ & $0.59 \%$ & $0.82 \%$ & $0.22 \%$ & $0.39 \%$ \\
2003 & $2.27 \%$ & $-0.65 \%$ & $-0.20 \%$ & $3.12 \%$ & $1.24 \%$ & $1.88 \%$ & $1.24 \%$ & $0.70 \%$ \\
2004 & $3.05 \%$ & $0.39 \%$ & $0.08 \%$ & $2.58 \%$ & $0.52 \%$ & $2.06 \%$ & $0.97 \%$ & $0.32 \%$ \\
2005 & $1.31 \%$ & $0.34 \%$ & $-0.81 \%$ & $1.79 \%$ & $-0.63 \%$ & $2.42 \%$ & $1.15 \%$ & $1.41 \%$ \\
2006 & $1.71 \%$ & $0.73 \%$ & $-0.27 \%$ & $1.25 \%$ & $0.58 \%$ & $0.67 \%$ & $0.73 \%$ & $0.46 \%$ \\
2007 & $4.69 \%$ & $0.98 \%$ & $0.43 \%$ & $3.28 \%$ & $1.47 \%$ & $1.81 \%$ & $0.97 \%$ & $0.12 \%$ \\
2008 & $0.12 \%$ & $0.49 \%$ & $0.30 \%$ & $-0.67 \%$ & $-1.51 \%$ & $0.84 \%$ & $0.77 \%$ & $0.14 \%$ \\
2009 & $-2.35 \%$ & $-2.43 \%$ & $-0.07 \%$ & $0.15 \%$ & $-0.98 \%$ & $1.13 \%$ & $0.02 \%$ & $1.07 \%$ \\
\hline Average & $1.99 \%$ & $0.32 \%$ & $0.08 \%$ & $1.59 \%$ & $0.23 \%$ & $1.36 \%$ & $0.91 \%$ & $0.37 \%$ \\
\hline \hline
\end{tabular}

(2009). Real capital stock is deflated book value of tangible fixed assets. 


\section{C.3 Output Production Function}

Table C.3: Output Production Function

\begin{tabular}{lcccccccccc}
\hline \hline Year & Val. Ad. & Labor & Capital & APG & Within & Reall. & & & \\
& & & & & & & Labor & Capital & Mat. & FC \\
\hline 1998 & $3.75 \%$ & $2.05 \%$ & $0.76 \%$ & $0.94 \%$ & $-14.73 \%$ & $15.67 \%$ & $0.34 \%$ & $-0.41 \%$ & $3.02 \%$ & $12.71 \%$ \\
1999 & $3.93 \%$ & $1.19 \%$ & $0.32 \%$ & $2.42 \%$ & $11.10 \%$ & $-8.67 \%$ & $-0.16 \%$ & $-0.31 \%$ & $1.79 \%$ & $-9.99 \%$ \\
2000 & $3.59 \%$ & $0.70 \%$ & $0.31 \%$ & $2.58 \%$ & $2.94 \%$ & $-0.35 \%$ & $0.25 \%$ & $-1.16 \%$ & $1.55 \%$ & $-1.00 \%$ \\
2001 & $1.34 \%$ & $2.03 \%$ & $0.32 \%$ & $-1.02 \%$ & $-1.60 \%$ & $0.59 \%$ & $0.22 \%$ & $-0.33 \%$ & $0.38 \%$ & $0.32 \%$ \\
2002 & $0.16 \%$ & $-0.63 \%$ & $-0.23 \%$ & $1.02 \%$ & $3.96 \%$ & $-2.94 \%$ & $0.48 \%$ & $0.47 \%$ & $-1.92 \%$ & $-1.97 \%$ \\
2003 & $1.62 \%$ & $-1.59 \%$ & $-0.11 \%$ & $3.33 \%$ & $0.00 \%$ & $3.33 \%$ & $0.13 \%$ & $0.13 \%$ & $1.25 \%$ & $1.81 \%$ \\
2004 & $1.95 \%$ & $-0.18 \%$ & $0.13 \%$ & $1.99 \%$ & $-2.48 \%$ & $4.48 \%$ & $-0.40 \%$ & $0.51 \%$ & $2.28 \%$ & $2.08 \%$ \\
2005 & $0.67 \%$ & $0.08 \%$ & $-1.08 \%$ & $1.67 \%$ & $-4.17 \%$ & $5.84 \%$ & $0.42 \%$ & $1.23 \%$ & $1.81 \%$ & $2.38 \%$ \\
2006 & $0.36 \%$ & $0.08 \%$ & $-0.26 \%$ & $0.54 \%$ & $-3.31 \%$ & $3.85 \%$ & $1.29 \%$ & $0.84 \%$ & $1.80 \%$ & $-0.08 \%$ \\
2007 & $4.09 \%$ & $1.29 \%$ & $0.48 \%$ & $2.32 \%$ & $-1.28 \%$ & $3.60 \%$ & $0.68 \%$ & $-0.54 \%$ & $1.52 \%$ & $1.94 \%$ \\
2008 & $1.03 \%$ & $0.83 \%$ & $0.61 \%$ & $-0.41 \%$ & $-1.39 \%$ & $0.98 \%$ & $0.19 \%$ & $0.19 \%$ & $1.01 \%$ & $-0.41 \%$ \\
2009 & $-2.71 \%$ & $-3.00 \%$ & $-0.26 \%$ & $0.54 \%$ & $0.31 \%$ & $0.24 \%$ & $0.16 \%$ & $2.24 \%$ & $-3.52 \%$ & $1.36 \%$ \\
\hline Average & $1.65 \%$ & $0.24 \%$ & $0.08 \%$ & $1.33 \%$ & $-0.89 \%$ & $2.22 \%$ & $0.30 \%$ & $0.24 \%$ & $0.92 \%$ & $0.76 \%$ \\
\hline \hline
\end{tabular}




\section{C.4 Cobb-Douglas production function}

Table C.4: Cobb-Dougals Production Function

\begin{tabular}{lcccccccc}
\hline \hline Year & Val. Ad. & Labor & Capital & APG & Within & Reallocation & \\
& & & & & & & Labor & Capital \\
\hline 1998 & $4.25 \%$ & $2.36 \%$ & $0.82 \%$ & $1.06 \%$ & $0.42 \%$ & $0.64 \%$ & $0.93 \%$ & $-0.50 \%$ \\
1999 & $3.50 \%$ & $0.40 \%$ & $0.28 \%$ & $2.82 \%$ & $2.43 \%$ & $0.39 \%$ & $0.89 \%$ & $-0.16 \%$ \\
2000 & $3.12 \%$ & $0.61 \%$ & $0.31 \%$ & $2.21 \%$ & $1.74 \%$ & $0.46 \%$ & $1.17 \%$ & $-0.32 \%$ \\
2001 & $0.32 \%$ & $0.78 \%$ & $0.07 \%$ & $-0.53 \%$ & $-1.00 \%$ & $0.47 \%$ & $0.84 \%$ & $-0.04 \%$ \\
2002 & $0.47 \%$ & $-0.98 \%$ & $-0.13 \%$ & $1.58 \%$ & $1.41 \%$ & $0.17 \%$ & $0.45 \%$ & $-0.13 \%$ \\
2003 & $1.93 \%$ & $-0.90 \%$ & $0.00 \%$ & $2.83 \%$ & $2.37 \%$ & $0.45 \%$ & $0.85 \%$ & $-0.07 \%$ \\
2004 & $2.58 \%$ & $-0.03 \%$ & $0.20 \%$ & $2.40 \%$ & $1.28 \%$ & $1.13 \%$ & $0.90 \%$ & $-0.10 \%$ \\
2005 & $0.84 \%$ & $-0.04 \%$ & $-0.75 \%$ & $1.62 \%$ & $0.19 \%$ & $1.43 \%$ & $1.11 \%$ & $0.58 \%$ \\
2006 & $1.31 \%$ & $0.54 \%$ & $-0.11 \%$ & $0.87 \%$ & $0.84 \%$ & $0.03 \%$ & $0.45 \%$ & $0.10 \%$ \\
2007 & $4.38 \%$ & $1.04 \%$ & $0.36 \%$ & $2.99 \%$ & $2.40 \%$ & $0.59 \%$ & $0.62 \%$ & $-0.18 \%$ \\
2008 & $-0.13 \%$ & $0.29 \%$ & $0.39 \%$ & $-0.81 \%$ & $-1.01 \%$ & $0.21 \%$ & $0.65 \%$ & $-0.31 \%$ \\
2009 & $-2.44 \%$ & $-2.59 \%$ & $-0.32 \%$ & $0.46 \%$ & $0.48 \%$ & $-0.01 \%$ & $0.72 \%$ & $-0.09 \%$ \\
\hline Average & $1.68 \%$ & $0.12 \%$ & $0.09 \%$ & $1.46 \%$ & $0.96 \%$ & $0.50 \%$ & $0.80 \%$ & $-0.10 \%$ \\
\hline
\end{tabular}




\section{Detailed Classification of Sectors}

Figure D.1: Sector-Specific Growth Rates Productivity

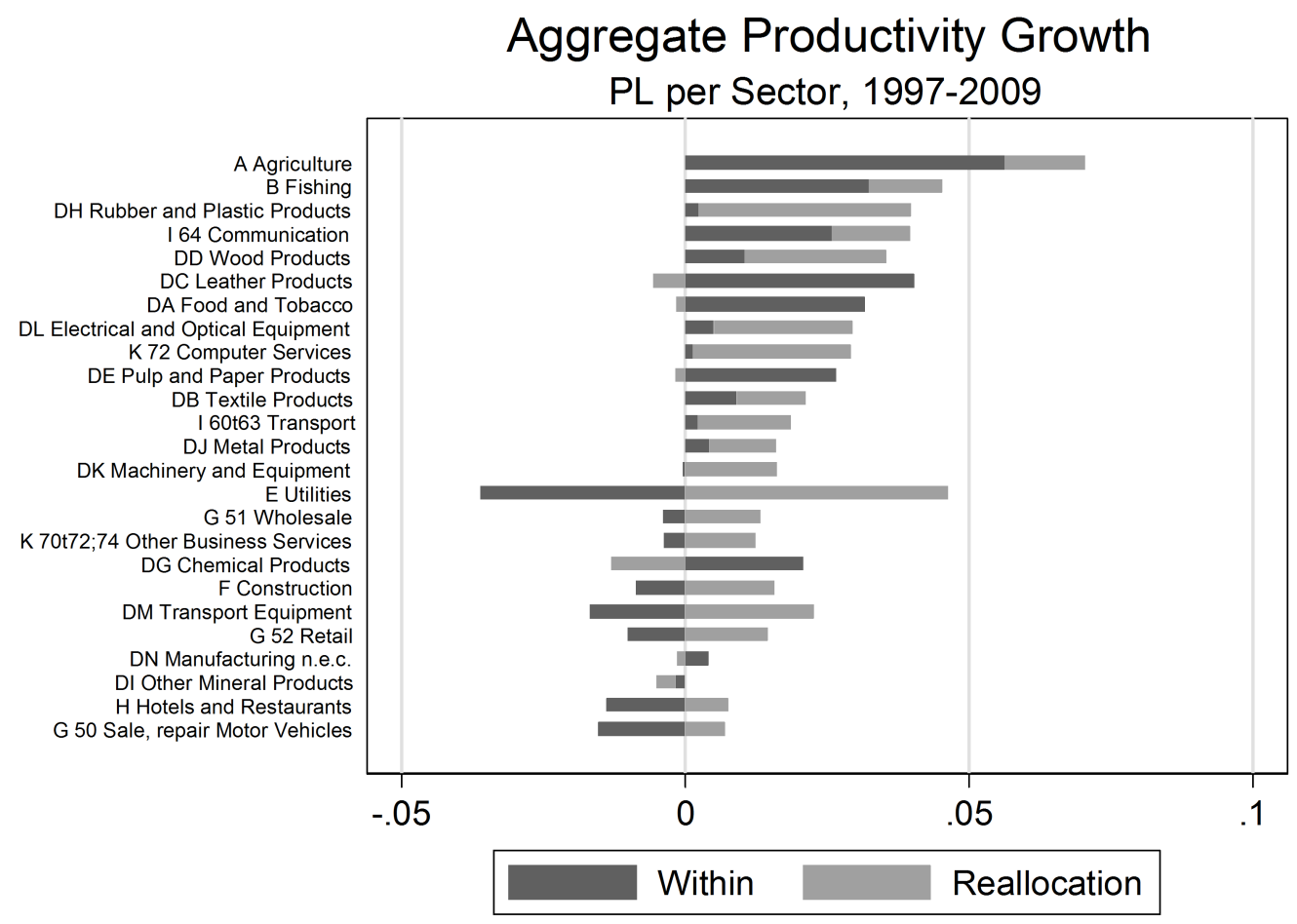




\section{NATIONAL BANK OF BELGIUM - WORKING PAPERS SERIES}

The Working Papers are available on the website of the Bank: http://www.nbb.be.

209. "Wage and employment effects of a wage norm: The Polish transition experience" by A. de Crombrugghe and G. de Walque, Research series, February 2011.

210. "Estimating monetary policy reaction functions: A discrete choice approach" by J. Boeckx, Research series, February 2011.

211. "Firm entry, inflation and the monetary transmission mechanism" by V. Lewis and C. Poilly, Research series, February 2011.

212. "The link between mobile telephony arrears and credit arrears" by H. De Doncker, Document series, March 2011.

213. "Development of a financial health indicator based on companies' annual accounts", by D. Vivet, Document series, April 2011.

214. "Wage structure effects of international trade: Evidence from a small open economy", by Ph. Du Caju, F. Rycx and I. Tojerow, Research series, April 2011.

215. "Economic importance of the Belgian ports: Flemish maritime ports, Liège port complex and the port of Brussels - Report 2009", by C. Mathys, Document series, June 2011.

216. "Verti-zontal differentiation in monopolistic competition", by F. Di Comite, J.-F. Thisse and H. Vandenbussche, Research series, October 2011.

217. "The evolution of Alexandre Lamfalussy's thought on the international and European monetary system (1961-1993)" by I. Maes, Research series, November 2011.

218. "Economic importance of air transport and airport activities in Belgium - Report 2009", by X. Deville and S. Vennix, Document series, December 2011.

219. "Comparative advantage, multi-product firms and trade liberalisation: An empirical test", by C. Fuss and L. Zhu, Research series, January 2012.

220. "Institutions and export dynamics", by L. Araujo, G. Mion and E. Ornelas, Research series, February 2012.

221. "Implementation of EU legislation on rail liberalisation in Belgium, France, Germany and the Netherlands", by X. Deville and F. Verduyn, Document series, March 2012.

222. "Tommaso Padoa-Schioppa and the origins of the euro", by I. Maes, Document series, March 2012.

223. "(Not so) easy come, (still) easy go? Footloose multinationals revisited", by P. Blanchard, E. Dhyne, C. Fuss and C. Mathieu, Research series, March 2012.

224. "Asymmetric information in credit markets, bank leverage cycles and macroeconomic dynamics", by A. Rannenberg, Research series, April 2012.

225. "Economic importance of the Belgian ports: Flemish maritime ports, Liège port complex and the port of Brussels - Report 2010", by C. Mathys, Document series, July 2012.

226. "Dissecting the dynamics of the US trade balance in an estimated equilibrium model", by P. Jacob and G. Peersman, Research series, August 2012.

227. "Regime switches in volatility and correlation of financial institutions", by K. Boudt, J. Daníelsson, S.J. Koopman and A. Lucas, Research series, October 2012.

228. "Measuring and testing for the systemically important financial institutions", by C. Castro and S. Ferrari, Research series, October 2012.

229. "Risk, uncertainty and monetary policy", by G. Bekaert, M. Hoerova and M. Lo Duca, Research series, October 2012.

230. "Flights to safety", by L. Baele, G. Bekaert, K. Inghelbrecht and M. Wei, Research series, October 2012.

231. "Macroprudential policy, countercyclical bank capital buffers and credit supply: Evidence from the Spanish dynamic provisioning experiments", by G. Jiménez, S. Ongena, J.-L. Peydró and J. Saurina, Research series, October 2012.

232. "Bank/sovereign risk spillovers in the European debt crisis", by V. De Bruyckere, M. Gerhardt, G. Schepens and R. Vander Vennet, Research series, October 2012.

233. "A macroeconomic framework for quantifying systemic risk", by Z. He and A. Krishnamurthy, Research series, October 2012.

234. "Fiscal policy, banks and the financial crisis", by R. Kollmann, M. Ratto, W. Roeger and J. in't Veld, Research series, October 2012.

235. "Endogenous risk in a DSGE model with capital-constrained financial intermediaries", by $\mathrm{H}$. Dewachter and R. Wouters, Research series, October 2012.

236. "A macroeconomic model with a financial sector", by M.K. Brunnermeier and Y. Sannikov, Research series, October 2012.

237. "Services versus goods trade: Are they the same?", by A. Ariu, Research series, December 2012. 
238. "Importers, exporters, and exchange rate disconnect", by M. Amiti, O. Itskhoki and J. Konings, Research series, December 2012.

239. "Concording EU trade and production data over time", by I. Van Beveren, A.B. Bernard and $\mathrm{H}$. Vandenbussche, Research series, December 2012.

240. "On the origins of the Triffin dilemma: Empirical business cycle analysis and imperfect competition theory", by I. Maes, Research series, December 2012.

241. "The Influence of the Taylor rule on US monetary policy", by P. Ilbas, $\varnothing$. Røisland and T. Sveen, Research series, January 2013.

242. "Economic importance of the Belgian ports: Flemish maritime ports, Liège port complex and the port of Brussels - Report 2011", by C. Mathys, Document series, July 2013.

243. "The fragility of two monetary regimes: The European Monetary System and the Eurozone", by P. De Grauwe and Y. Ji, Research series, October 2013.

244. "Funding liquidity, market liquidity and TED spread: A two-regime model", by K. Boudt, E. C.S. Paulus and D. W.R. Rosenthal, Research series, November 2013.

245. "Robustifying optimal monetary policy using simple rules as cross-checks", by P. Ilbas, $\varnothing$. Røisland and T. Sveen, Research series, November 2013.

246. "Household and firm leverage, capital flows and monetary policy in a small open economy", by M. Pirovano, Research series, November 2013.

247. "The BIS and the Latin American debt crisis of the 1980s", by P. Clement and I. Maes, Research series, December 2013.

248. "The importance of the right amount of business resources for firms' exporting behavior", by I. Paeleman, C. Fuss and T. Vanacker, Research series, December 2013.

249. "The role of financial frictions during the crisis: An estimated DSGE model", by R. Merola, Research series, December 2013.

250. "Bank reactions after capital shortfalls", by C. Kok and G. Schepens, Research series, December 2013.

251. "Why firms avoid cutting wages: Survey evidence from European firms", by P. Du Caju, T. Kosma, M. Lawless, J. Messina and T. Rõõm, Research series, December 2013.

252. "The distribution of debt across euro area countries: The role of individual characteristics, institutions and credit conditions", by O. Bover, J. M. Casado, S. Costa, Ph. Du Caju, Y. McCarthy, E. Sierminska, P. Tzamourani, E. Villanueva and T. Zavadil, Research series, December 2013.

253. "Micro-based evidence of EU competitiveness: The CompNet database", by CompNet Task Force, Research series, March 2014.

254. "Information in the yield curve: A macro-finance approach", by H. Dewachter, L. lania and M. Lyrio, Research series, March 2014.

255. "The Single supervisory mechanism or 'SSM', part one of the Banking Union", by E. Wymeersch, Research series, April 2014.

256. "Nowcasting Belgium", by D. de Antonio Liedo, Research series, April 2014.

257. "Human capital, firm capabilities and productivity growth", by I. Van Beveren and S. Vanormelingen, Research series, May 2014. 
National Bank of Belgium

Limited liability company

RLP Brussels - Company's number: 0203.201.340

Registered office: boulevard de Berlaimont $14-B E-1000$ Brussels

www.nbb.be

\section{Editor}

\section{Jan Smets}

Member of the Board of directors of the National Bank of Belgium

(C) Illustrations: National Bank of Belgium

Layout: Analysis and Research Group Cover: NBB AG - Prepress \& Image

Published in May 2014 